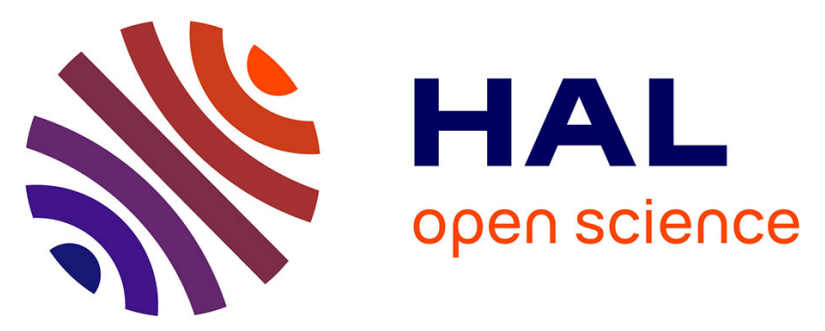

\title{
Petrophysical property modifications by alteration in a volcanic sequence at IODP Site U1513, Naturaliste Plateau
}

Eun Young Lee, Maria Luisa G Tejada, Insun Song, Seung Soo Chun, Susanne Gier, Laurent Riquier, Lloyd T White, Bernhard Schnetger, Hans-jürgen

Brumsack, Matthew M Jones, et al.

\section{To cite this version:}

Eun Young Lee, Maria Luisa G Tejada, Insun Song, Seung Soo Chun, Susanne Gier, et al.. Petrophysical property modifications by alteration in a volcanic sequence at IODP Site U1513, Naturaliste Plateau. Journal of Geophysical Research: Solid Earth, 2021, 126 (10), pp.e2020JB021061. 10.1029/2020JB021061 . insu-03330557v2

\section{HAL Id: insu-03330557}

\section{https://hal-insu.archives-ouvertes.fr/insu-03330557v2}

Submitted on 20 Oct 2021

HAL is a multi-disciplinary open access archive for the deposit and dissemination of scientific research documents, whether they are published or not. The documents may come from teaching and research institutions in France or abroad, or from public or private research centers.
L'archive ouverte pluridisciplinaire HAL, est destinée au dépôt et à la diffusion de documents scientifiques de niveau recherche, publiés ou non, émanant des établissements d'enseignement et de recherche français ou étrangers, des laboratoires publics ou privés. 


\section{JGR Solid Earth}

\section{RESEARCH ARTICLE}

10.1029/2020JB021061

Key Points:

- Petrophysical properties of a volcanic sequence at International Ocean Discovery Program Site U1513 on the Naturaliste Plateau were modified by alteration processes

- Distinct trends are indicated in correlations of petrophysical variations with alteration intensity and lithologic characteristics

- This study provides synthesis models of petrophysical parameters corresponding to alteration intensity

Correspondence to:

E. Y. Lee, M. L. G. Tejada, and I. Song, eun.y.lee@chonnam.ac.kr; eun.lee@univie.ac.at; mtejada@jamstec.go.jp; isong@kigam.re.kr

Citation:

Lee, E. Y., Tejada, M. L. G., Song, I., Chun, S. S., Gier, S., Riquier, L., et al. (2021). Petrophysical property modifications by alteration in a volcanic sequence at IODP Site U1513, Naturaliste Plateau. Journal of Geophysical Research: Solid Earth, 126, e2020JB021061. https://doi. org/10.1029/2020JB021061

Received 1 OCT 2020

Accepted 25 AUG 2021
(C) 2021. American Geophysical Union. All Rights Reserved.

\section{Petrophysical Property Modifications by Alteration in a Volcanic Sequence at IODP Site U1513, Naturaliste Plateau}

\author{
Eun Young Lee L,2 $^{(D)}$, Maria Luisa G. Tejada ${ }^{3}$ (D), Insun Song ${ }^{(\mathbb{D})}$, Seung Soo Chun ${ }^{1}$ (D), \\ Susanne Gier ${ }^{2}$ (D) , Laurent Riquier ${ }^{5}$ (D), Lloyd T. White ${ }^{6}$ (D), Bernhard Schnetger ${ }^{7}$ (D), \\ Hans-Jürgen Brumsack ${ }^{7}$ (D), Matthew M. Jones ${ }^{8}$ (D), and Mathieu Martinez ${ }^{9}$ (D)
}

\begin{abstract}
${ }^{1}$ Faculty of Earth Systems and Environmental Sciences, Chonnam National University, Gwangju, Republic of Korea, ${ }^{2}$ Department of Geology, University of Vienna, Vienna, Austria, ${ }^{3}$ Institute for Marine Geodynamics (IMG), Japan Agency for Marine-Earth Science and Technology (JAMSTEC), Yokosuka, Japan, ${ }^{4}$ Petroleum and Marine Division, Korea Institute of Geoscience and Mineral Resources (KIGAM), Daejeon, Republic of Korea, ${ }^{5}$ Institut des Sciences de la Terre de Paris (ISTeP), Sorbonne University, Paris, France, ${ }^{6}$ GeoQuEST Research Centre, School of Earth, Atmospheric and Life Sciences, University of Wollongong, Wollongong, NSW, Australia, ${ }^{7}$ Institute for Chemistry and Biology of the Marine Environment (ICBM), University of Oldenburg, Oldenburg, Germany, ${ }^{8}$ Earth and Environmental Sciences Department, University of Michigan, Ann Arbor, MI, USA, ${ }^{9}$ Univ Rennes, CNRS, Géosciences Rennes, UMR 6118, Rennes, France
\end{abstract}

Abstract Petrophysical properties of volcanic rocks are controlled by lithology and subsequent modification by alteration processes. Investigating the linkages, using a range of different techniques, are important to establish how petrophysical properties can inform about the alteration state of volcanic rocks. Here, we compile petrophysical data and correlate these with geochemical and mineralogical analyses acquired from a volcanic sequence on the Naturaliste Plateau, offshore southwest Australia (International Ocean Discovery Program Site U1513). The sequence consists of alternating basalt lava flows and volcaniclastic deposits, intruded by multiple dolerite dikes. Variable alteration intensities from fresh-slight to strong are quantified using Chemical Index of Alteration. Intervals of slightly altered dikes exhibit low porosity and high values of bulk density, $P$-wave velocity, and thermal conductivity. The increase of alteration intensity corresponds to decreases in bulk density to $\sim 2 \mathrm{~g} / \mathrm{cm}^{3}, P$-wave velocity to $\sim 2,000 \mathrm{~m} / \mathrm{s}$, thermal conductivity to $\sim 1.2 \mathrm{~W} /(\mathrm{m} \cdot \mathrm{K})$ and an increase in porosity up to $50 \%$. Natural Gamma Ray and magnetic susceptibility vary downhole with rock composition and at lithologic boundaries. The distinct variations exhibit a good correlation with primary lithologic characteristics and secondary mineralogical and textural changes attributed to alteration processes. We provide synthesis models of petrophysical variation with alteration intensity. Although differences in primary lithology and alteration type introduce limitations and uncertainties, there is a reasonable applicability of our results to rapidly characterize the alteration intensity and volcanic stratigraphy in volcanic sequences and to calibrate wireline log-based determinations. This will help others to develop strategies for exploration, drilling, and geophysical research of volcanic rocks.

Plain Language Summary We present the physical properties of rocks comprising a volcanic sequence recovered from the eastern Naturaliste Plateau, offshore southwest Australia. The sequence consists of basalt lava flows and volcaniclastic deposits, which are intruded by multiple dikes. Petrophysical properties of the volcanic rocks are variable with lithology and alteration state. To investigate the linkages, we applied a range of different techniques to correlate petrophysical data with geochemical and mineralogical analyses. The alteration intensity was quantified based on chemical composition into four ranges; fresh-slight, weak, moderate, and strong. Relatively fresh basalt intervals exhibit low porosity and high values of bulk density, $P$-wave velocity, and thermal conductivity. Increases of alteration intensity correspond to decreases in bulk density to $\sim 2 \mathrm{~g} / \mathrm{cm}^{3}, P$-wave velocity to $\sim 2,000$ $\mathrm{m} / \mathrm{s}$, thermal conductivity to $\sim 1.2 \mathrm{~W} /(\mathrm{m} \cdot \mathrm{K})$, and an increase in porosity up to $50 \%$. Natural Gamma Ray and magnetic susceptibility vary with rock composition and at lithologic boundaries. The petrophysical variations were associated with primary lithologic characteristics, secondary mineralogical and textural changes. We provide synthesis models of petrophysical variation with alteration intensity. Our results can 
be used to rapidly characterize the alteration intensity and volcanic stratigraphy in volcanic sequences and to develop strategies for exploration, drilling, and research of volcanic rocks.

\section{Introduction}

Volcanic rocks are a widespread geologic feature on the Earth's surface, and they have been studied intensively in various geoscientific fields and in exploration campaigns for economic mineral deposits. In recent years, the continental flood basalts have received attention as reservoirs of hydrocarbon accumulation (e.g., Jiang et al., 2017; Wang et al., 2018), potential targets for long-term storage of anthropogenic carbon dioxide $\left(\mathrm{CO}_{2}\right)$ (e.g., Gislason \& Oelkers, 2014; McGrail et al., 2006; Zakharova et al., 2012), and as fields of geothermal energy (e.g., Delayre et al., 2020; Kristinsdóttir et al., 2010; Scott et al., 2019). However, volcanic rocks are commonly chemically and physically altered by weathering processes and hydrothermal fluids, affecting reservoir potential. Alteration records of volcanic units preserve complex geologic histories of dynamic hydrothermal systems along with emplacement and periods of exposure (e.g., Figueiredo e Silva et al., 2020; Navelot et al., 2018; Schlegel \& Heinrich, 2015). Since feldspar and mafic minerals weather in part to clay minerals (e.g., smectite group), clay mineral assemblages are commonly analyzed to evaluate the alteration intensity of volcanic rocks (Alt et al., 1986, 1996; 2010; Bain et al., 1980; Broglia \& Moos, 1988; Büchl \& Gier, 2003; Çelik et al., 1999; Houston \& Smith, 1997). Increase of clay mineral proportions by alteration processes cause petrophysical variations in altered rocks. Igneous minerals and clay minerals exhibit distinctly different petrophysical properties, such as grain density, porosity, $P$-wave velocity, thermal conductivity, and so on. In this study, we introduce a framework to evaluate petrophysical property variations corresponding to alteration intensity. The approach is based on qualitative and quantitative correlations of lithologic descriptions, petrophysical properties, and mineralogical/geochemical alteration analyses from a volcanic sequence of the submarine Naturaliste Plateau, offshore southwest Australia (Figure 1).

Previous studies have reported the effects of alteration on petrophysical properties of volcanic rocks (Carlson, 2001, 2014; Christeson et al., 2016; Fontana \& Tartarotti, 2013; Navelot et al., 2018; Planke, Alvestad \& Eldholm, 1999; Planke, Cerney, et al., 1999; Pola et al., 2012; Tartarotti et al., 2009; Wyering et al., 2014; Zakharova et al., 2012). However, an integrated approach that compare a range of petrophysical properties to quantified alteration intensity has been insufficient to establish a framework. In offshore drilling with onboard measurements and logging, it may be overlooked solely due to the time-limited description routine. Precise alteration intensity and type are commonly determined long after collection from high-resolution mineralogical and geochemical analyses. However, understanding complex alteration mineralogy is difficult for geoscientists and geoengineers using quantitative petrophysical data. Non-scientific drilling rarely recovers cores from altered volcanic rocks due to cost and technical difficulty, thus alteration mineralogy is derived from cuttings in coordination with wireline log data. Subsequently, quantifying alteration and its correlation with petrophysical properties has faced obstacles in similar studies (e.g., Broglia \& Moos, 1988; Delius et al., 2003; Greenfield et al., 2020; Helm-Clark et al., 2004; Jerram et al., 2019; Planke, 1994; Pola et al., 2014). Our study builds on recent studies that have begun establishing the quantitative correlations between petrophysical properties and alteration (e.g., Delayre et al., 2020; Lévy et al., 2018; Rossetti et al., 2019; Scott et al., 2019). Although similar investigations regarding the relationships between petrophysical variation and diagenesis in sedimentary rocks have been extensively studied (e.g., Bjørlykke, 2014; Giles, 1997; Lee et al., 2021), the results are not applicable to altered volcanic rocks particularly due to changes in mineralogy and associated mineralization (Aspandiar \& Eggleton, 2002; Chesworth et al., 2004; García-Romero et al., 2005; Giggenbach, 1984; Schlegel \& Heinrich, 2015).

The volcanic sequence on the Naturaliste Plateau (Figure 1b) was recovered at Site U1513 by International Ocean Discovery Program (IODP) Expedition 369, with a total cored thickness of $82.2 \mathrm{~m}$ and consists of basalt lava flows, intercalated volcaniclastic deposits, and dolerite dikes (Figure 2a; Huber et al., 2019b; Tejada et al., 2020). The volcanic rocks were emplaced during Valanginian to early Hauterivian time, which are associated with the Greater Kerguelen Large Igneous Province and the breakup of Greater India from eastern Gondwana. Intercalated volcaniclastic deposits suggest that multiple phases of eruption took place in response to episodic continental rifting events (Direen et al., 2017; Harry et al., 2020; Olierook et al., 2017; White et al., 2021). Following the cessation of volcanism, the Naturaliste Plateau subsided to mid-lower 
a)


b)



Figure 1. (a) Location of International Ocean Discovery Program (IODP) Site U1513 on the eastern flank of the Naturaliste Plateau, offshore southwest Australia (Huber et al., 2019b; Tejada et al., 2020). Bathymetric contour interval is $500 \mathrm{~m}$ (Borissova, 2002). Location of a seismic section across Site U1513 (blue line). (b) Seismic line S310/07 (provided by Geoscience Australia) showing general lithostratigraphy of Site U1513, the assumed extent of the volcanic rocks (red line), and structural characteristics (revised from Lee et al., 2020).

bathyal depths during the Aptian-Albian, which lies in water depths of 2,000-5,000 m at present (Borissova, 2002; Lee et al., 2020).

Significant correlations between petrophysical properties, lithology, and alteration were observed in the volcanic sequence of Hole D at Site U1513 during the expedition. These data were used as input to correlate the lithologic boundaries in Hole $\mathrm{E}$ and collect samples for post-expedition analyses. The results highlight the importance of systematic acquisition and assessment of petrophysical properties in altered volcanic rocks for application in geoscientific research and sampling strategies of geological exploration projects. Since the volcanic sequence was variably altered, it is a good target to investigate how petrophysical properties are modified by alteration state. Shipboard petrophysical data including grain density, bulk density, porosity, $P$-wave velocity, thermal conductivity, Natural Gamma Ray (NGR), and magnetic susceptibility were collected using core sections and discrete core samples (Huber et al., 2019a, 2019b). After the expedition, grain density, bulk density, porosity, and $P$ - and $S$-wave velocity of Hole E section were acquired using discrete core samples. The bulk composition and mineralogy of discrete samples were analyzed to determine primary lithology, mineral assemblages, and alteration intensity. Here, we compare the petrophysical data with the lithologic, geochemical, and mineralogical data throughout the cored volcanic sequence at Site U1513.

\section{Materials and Methods}

\subsection{Core Description and Mineralogical Identification}

The volcanic rocks (Lithostratigraphic Unit VI) on the eastern Naturaliste Plateau were recovered at Hole D (latitude $33^{\circ} 47.6196^{\prime} \mathrm{S}$, longitude $112^{\circ} 29.1339^{\prime} \mathrm{E}$ ) and Hole E (latitude $33^{\circ} 47.6190^{\prime} \mathrm{S}$, longitude $112^{\circ} 29.1204^{\prime} \mathrm{E}$ ) at Site U1513 (Figure 1a). Color, lithology, lithologic contacts and types, flow boundaries, 
a) Lithostratigraphy

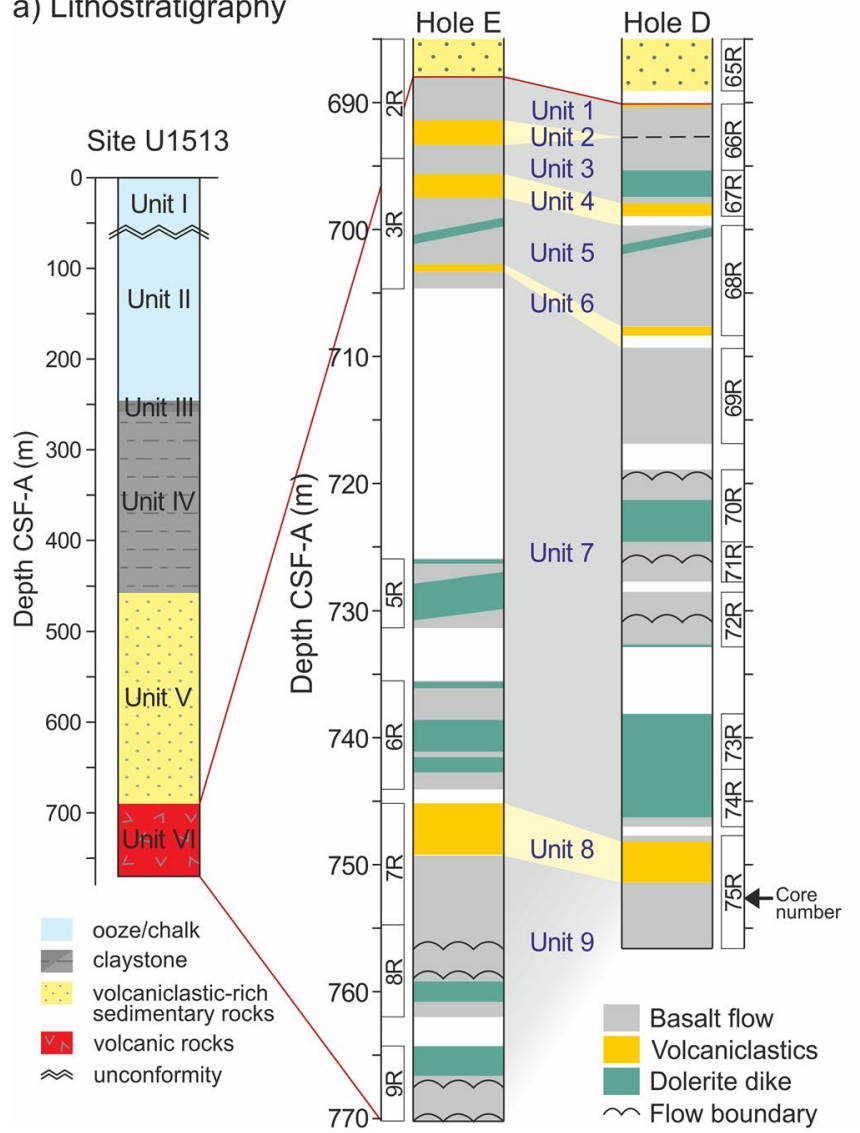

b) Core section images

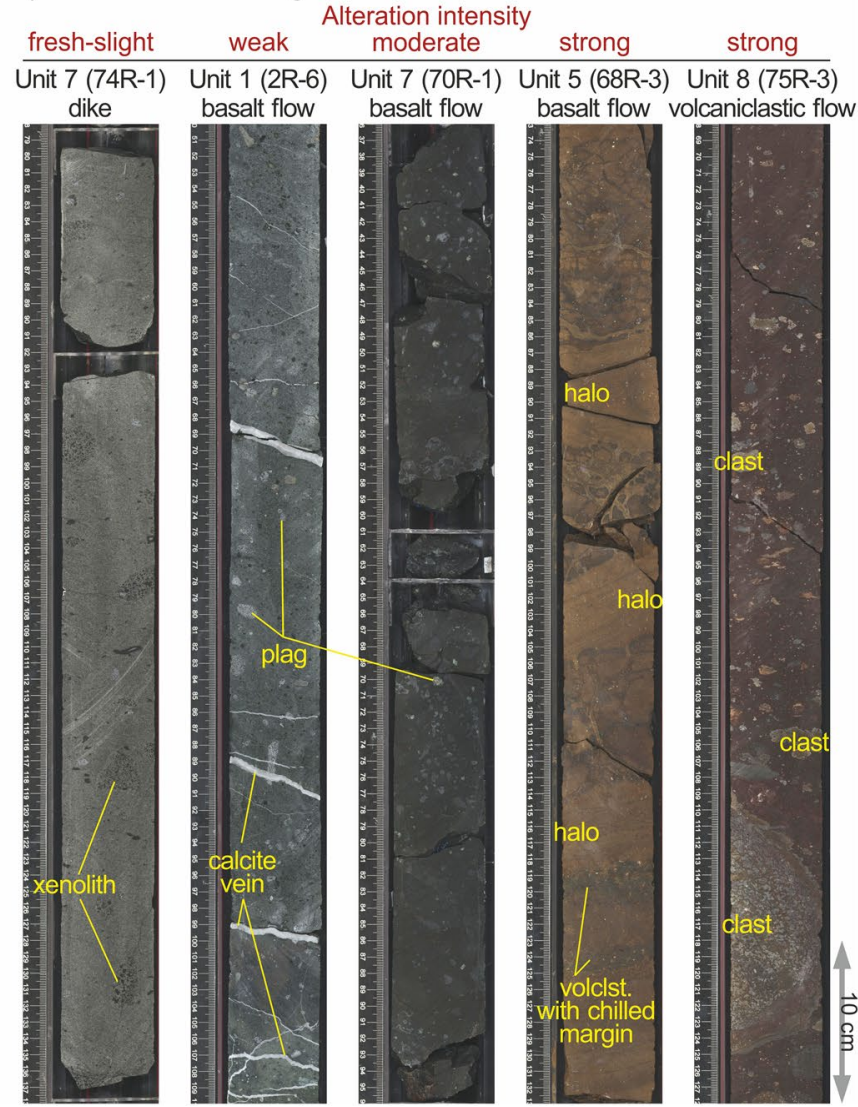

Figure 2. (a) Lithostratigraphy and lithology of the volcanic sequence (Lithostratigraphy Unit VI) at Site U1513 with core numbers (revised from Tejada et al., 2020). CSF-A: core depth below seafloor, Method A. The volcanic sequence is described in Cores $2 \mathrm{R}$ through $9 \mathrm{R}$ of Hole $\mathrm{E}$ and Cores $66 \mathrm{R}$ through $75 \mathrm{R}$ of Hole D. Basalt units are Units 1, 3, 5, 7, and 9, and volcaniclastic units are Units 2, 4, 6, and 8. Dolerite dikes intrude the whole volcanic sequence. (b) Core images of representative volcanic rocks for each alteration intensity from Holes D and E. Fresh-slightly altered fine-grained aphyric dolerite dike with xenolith of porphyritic basalt (Unit 7; U1513D-74R-1, 78-138 cm). Weakly altered green-gray porphyritic basalt flow with olivine, pyroxene, and large plagioclase phenocrysts in a fine-grained crystalline groundmass, and calcite veins (Unit 1; U1513E-2R-6, 50-110 cm). Moderately altered green-black basalt flow with plagioclase phenocrysts and clayey matrix (Unit 7; U1513D-70R-1, 36-96 cm). Strongly altered ochre-brown basalt flow with clayey and volcaniclastic matrix, chilled margin, haloes, and deformed/cracked bending structure (Unit 5; U1513D-68R-3, 73-133 cm). Strongly altered reddish brown volcaniclastic flow with ash-rich clayey matrix and granule- to pebble-sized fragments (Unit 8; U1513D-75R-3, 68-128 cm).

mineralogical composition and assemblage, igneous textures, vesicle distribution, and alteration minerals were described during the IODP Expedition 369. The core descriptions were combined with shipboard data from thin sections as well as whole-rock X-ray diffraction (XRD) mineral identification on 24 core samples of Hole D (Huber et al., 2019b). The whole-rock XRD analyses were completed using a Bruker D-4 Endeavor diffractometer mounted with a Vantec-1 detector using nickel-filtered $\mathrm{CuK} \alpha$ radiation. The standard locked coupled scan was conducted with voltage of $40 \mathrm{kV}$, current of $40 \mathrm{~mA}$, and measurement range of $4^{\circ}-70^{\circ} 2 \theta$ (Huber et al., 2019a).

After the expedition, the volcanic sequence at Hole D and Hole E was re-examined at the Kochi Core Center (KCC), Japan, and selected intervals were described in more detail. The descriptions were augmented by a re-examination of shipboard data, post-expedition XRD mineral identification data, and thin sections (Tejada et al., 2020). Additional whole-rock XRD analyses were conducted on 20 core samples of Hole E at the Korea Basic Science Institute (KBSI). These core samples were analyzed using a D8 Advance diffractometer with a $\mathrm{Cu}$ source, voltage of $40 \mathrm{kV}$, current of $40 \mathrm{~mA}$, and measurement range of $8^{\circ}-80^{\circ} 2 \theta$. Mineral phases of the XRD data were identified at Sorbonne University, France. Mineral identification of all shipboard and post-expedition XRD data was conducted using the X'pert HighScore Plus software and results were reported in Riquier et al. (2021). Six samples of sufficient volume were selected for clay fraction analysis to 
identify expandable clay minerals like smectite, vermiculite and mixed-layer minerals at the Department of Geology, University of Vienna, Austria using the method of Meszar et al. (2020). The clay samples were analyzed using a Panalytical PW 3040/60 X'Pert PRO diffractometer with CuKa radiation, 40 kV, 40 mA, step size $0.0167,5 \mathrm{~s}$ per step. The lithologic descriptions and XRD mineral data were used to determine alteration intensity and type in the volcanic sequence.

Samples of the volcaniclastic deposits were analyzed to verify the presence of microfossils and organic matter, considered to reflect higher NGR (e.g., De Vleeschouwer et al., 2017). A standard palynological pre-treatment method was used at the Korea Institute of Geoscience and Mineral Resources (KIGAM) (for method, see Kim et al., 2019). Phytoclasts were found from the volcaniclastic samples.

\subsection{Petrophysical Property Measurements}

In the shipboard laboratory, high-resolution petrophysical property measurements for the volcanic sequence were made on whole-round, archive-half and working-half core sections, and discrete core samples (Huber et al., 2019a, 2019b). Downhole wireline logging was not performed for the volcanic sequence. The selected core sections and discrete core samples were taken from what were deemed the most suitable and representative lithologic components of the cores, as well as from the least fractured core sections. For the Moisture and Density (MAD) analysis (Blum, 1997), 16 discrete core samples were collected from the working-half core sections at Hole D to determine grain density, bulk density, and porosity. Bulk density of whole-round core sections was estimated using Gamma Ray Attenuation (GRA) measurement (2.5 cm interval). GRA bulk density data measured at void or fractured intervals were not considered in this study (usually $<1.5 \mathrm{~g}$ / $\left.\mathrm{cm}^{3}\right) . P$-wave velocity measurement was performed using the $x$-axis caliper contact probe transducer for selected positions on the working-half core sections. Thermal conductivity was measured on the selected surface of working-half core sections with a heating power of 1.2-1.9 W/m (Huber et al., 2019a, 2019b). NGR was measured on the whole-round core sections $(10 \mathrm{~cm}$ interval and a gamma ray counting time of $5 \mathrm{~min}$ ) and resulting spectral data were then processed to estimate $\mathrm{K}$, Th, and $\mathrm{U}$ abundance (e.g., De Vleeschouwer et al., 2017). Magnetic susceptibility was measured on the archive-half core sections $(2.5 \mathrm{~cm}$ interval) using the Section Half Multisensor Logger (SHMSL) (Huber et al., 2019a). The instrument unit (IU) of magnetic susceptibility measurement is generally converted to dimensionless Système International (SI) unit $\times 10^{-5}$ (Searle, 2008). The shipboard petrophysical property data are available at http://web.iodp. tamu.edu/LORE/.

After the expedition, additional petrophysical property data were collected using discrete core samples at KIGAM. Twenty-seven samples (two samples from Hole D, 25 samples from Hole E) were selected for the MAD analysis using a five-celled Pentapyc 5200e helium gas pycnometer. Six samples in dry condition were selected to measure $P$-wave and $S$-wave velocity using a 5058PR high voltage ultrasonic pulser-receiver and a 12-bit $60 \mathrm{MHz}$ digitizer. The data are reported in Lee and Song (2021).

\subsection{Geochemical Analyses}

Bulk rock X-ray fluorescence (XRF) composition analysis was conducted on 82 core samples. Thirty-nine of these core samples were analyzed using AXIOS Plus (Panalytical) at the Institute for Chemistry and Biology of the Marine Environment (ICBM), University of Oldenburg, Germany. Borate glass beads were prepared from the sample powder using di-lithium tetraborate as a flux (700 $\mathrm{mg}$ sample and $4.2 \mathrm{~g}$ flux). Thirty-five core samples were analyzed using a Spectro Ametek XEPOS III energy dispersive XRF spectrometer at the University of Wollongong, Australia. Glass-fusion beads were analyzed to obtain major element data, recalculated to anhydrous values using the loss-on-ignition (LOI) measurement of each sample. Eight core samples were analyzed using AXIOS (Panalytical) at the Center for Research Facilities, Chonnam National University, Republic of Korea. Pellets were prepared from the sample powder mixed with wax binder ( $3 \mathrm{~g}$ sample, $0.3 \mathrm{~g}$ wax $\mathrm{C}_{18} \mathrm{H}_{36} \mathrm{O}_{2} \mathrm{~N}_{2}$ ). Several geological reference materials were run as unknowns alongside the basalt samples to ensure the results were accurate. Whole-rock major elements data are provided in Table 1.

In the volcanic sequence at Site U1513, the dominant alteration process is that fresh feldspars, mafic minerals, and groundmass are degraded toward clay minerals by chemical weathering and hydrothermal fluid (Tejada et al., 2020 and this study). To quantify the chemical changes due to alteration, we use the 
Table 1

Chemical Index of Alteration (CIA) Values and Whole-Rock X-Ray Fluorescence (XRF) Major Elements Data (wt\%) for (a) Hole D and (b) Hole E, Site U1513, IODP Expedition 369

\begin{tabular}{|c|c|c|c|c|c|c|c|c|c|c|c|c|c|c|}
\hline Sample interval & CIA & $\mathrm{SiO}_{2}$ & $\mathrm{TiO}_{2}$ & $\mathrm{Al}_{2} \mathrm{O}_{3}$ & $\mathrm{Fe}_{2} \mathrm{O}_{3}{ }^{*}$ & $\mathrm{MnO}$ & $\mathrm{MgO}$ & $\mathrm{CaO}$ & $\mathrm{Na}_{2} \mathrm{O}$ & $\mathrm{K}_{2} \mathrm{O}$ & $\mathrm{P}_{2} \mathrm{O}_{5}$ & Total & LOI & Ref. \\
\hline \multicolumn{15}{|l|}{ (a) Hole U1513D } \\
\hline $66 \mathrm{R}-1,112-116 \mathrm{~cm}$ & 48.9 & 48.42 & 0.58 & 20.39 & 8.43 & 0.11 & 9.71 & 9.47 & 2.53 & 0.04 & 0.04 & 99.74 & 7.62 & \\
\hline $66 \mathrm{R}-1,123-128 \mathrm{~cm}$ & 48.4 & 48.51 & 0.53 & 21.13 & 7.62 & 0.11 & 9.06 & 10.21 & 2.47 & 0.03 & 0.04 & 99.71 & 7.17 & \\
\hline $66 \mathrm{R}-3,66-69 \mathrm{~cm}$ & 47.2 & 49.46 & 0.54 & 21.39 & 6.36 & 0.12 & 8.49 & 10.92 & 2.51 & 0.03 & 0.04 & 99.85 & 2.97 & $\mathrm{a}$ \\
\hline $66 \mathrm{R}-3,82-86 \mathrm{~cm}$ & 50.1 & 48.96 & 0.55 & 18.89 & 8.46 & 0.14 & 12.04 & 8.30 & 2.30 & 0.04 & 0.04 & 99.74 & 8.95 & \\
\hline $66 \mathrm{R}-3,93-105 \mathrm{~cm}$ & 51.6 & 48.42 & 0.41 & 23.89 & 5.76 & 0.11 & 8.49 & 10.34 & 2.25 & 0.03 & 0.04 & 99.74 & 7.43 & \\
\hline $66 \mathrm{R}-4,43-46 \mathrm{~cm}$ & 69.1 & 49.40 & 0.33 & 25.18 & 6.48 & 0.15 & 11.60 & 4.25 & 1.51 & 0.97 & 0.01 & 99.88 & 9.00 & $\mathrm{a}$ \\
\hline $66 \mathrm{R}-4,82-90 \mathrm{~cm}$ & 65.8 & 49.17 & 0.28 & 25.92 & 5.62 & 0.14 & 10.76 & 5.34 & 1.62 & 1.00 & 0.00 & 99.85 & 13.12 & \\
\hline $66 \mathrm{R}-4,122-132 \mathrm{~cm}$ & 57.9 & 48.03 & 0.30 & 24.86 & 6.16 & 0.17 & 9.94 & 8.03 & 1.84 & 0.44 & 0.01 & 99.78 & 10.40 & \\
\hline $67 \mathrm{R}-1,25.5-28.5 \mathrm{~cm}$ & 47.7 & 48.66 & 0.53 & 18.81 & 8.45 & 0.15 & 11.56 & 9.32 & 2.29 & 0.03 & 0.04 & 99.85 & 3.74 & $\mathrm{a}$ \\
\hline $67 \mathrm{R}-2,58-73 \mathrm{~cm}$ & 46.3 & 48.59 & 0.55 & 19.42 & 8.02 & 0.16 & 10.26 & 10.30 & 2.36 & 0.04 & 0.04 & 99.75 & 5.83 & $\mathrm{~b}$ \\
\hline $67 \mathrm{R}-3,17.5-20.5 \mathrm{~cm}$ & 50.6 & 48.22 & 0.57 & 21.87 & 7.06 & 0.18 & 9.88 & 9.50 & 2.50 & 0.03 & 0.04 & 99.84 & 4.83 & $\mathrm{a}$ \\
\hline $67 \mathrm{R}-3,21-29 \mathrm{~cm}$ & 47.7 & 47.07 & 0.58 & 21.60 & 6.86 & 0.25 & 9.94 & 10.70 & 2.61 & 0.03 & 0.06 & 99.68 & 10.30 & \\
\hline $67 \mathrm{R}-4,62-65 \mathrm{~cm}$ & 90.6 & 40.01 & 2.36 & 31.62 & 22.32 & 0.07 & 1.08 & 1.45 & 0.52 & 0.17 & 0.16 & 99.76 & 10.96 & $\mathrm{a}$ \\
\hline $68 \mathrm{R}-1,28-30 \mathrm{~cm}$ & 85.8 & 45.60 & 1.16 & 23.73 & 10.85 & 0.15 & 14.60 & 1.98 & 0.62 & 0.50 & 0.52 & 99.72 & 13.01 & $\mathrm{a}$ \\
\hline $68 \mathrm{R}-4,123-126 \mathrm{~cm}$ & 69.6 & 49.37 & 1.52 & 20.34 & 13.18 & 0.29 & 9.75 & 3.13 & 1.73 & 0.52 & 0.09 & 99.92 & 10.48 & $\mathrm{a}$ \\
\hline $69 \mathrm{R}-1,74-76 \mathrm{~cm}$ & 76.6 & 48.43 & 1.81 & 21.15 & 21.42 & 0.14 & 3.14 & 2.31 & 1.11 & 0.41 & 0.01 & 99.95 & 8.59 & $\mathrm{a}$ \\
\hline $69 \mathrm{R}-2,66-68 \mathrm{~cm}$ & 54.0 & 46.89 & 1.39 & 18.13 & 13.92 & 0.28 & 10.15 & 6.09 & 2.59 & 0.36 & 0.12 & 99.91 & 6.47 & $\mathrm{a}$ \\
\hline $69 \mathrm{R}-4,59-61 \mathrm{~cm}$ & 59.3 & 51.52 & 1.37 & 19.36 & 11.66 & 0.17 & 7.88 & 4.70 & 2.38 & 0.85 & 0.05 & 99.93 & 5.30 & $\mathrm{a}$ \\
\hline $69 \mathrm{R}-4,95-102 \mathrm{~cm}$ & 62.2 & 51.47 & 1.22 & 18.61 & 11.97 & 0.17 & 9.61 & 3.63 & 2.31 & 0.87 & 0.01 & 99.88 & 17.29 & $\mathrm{~b}$ \\
\hline $70 \mathrm{R}-1,69.5-71.5 \mathrm{~cm}$ & 68.3 & 52.25 & 1.23 & 17.30 & 15.39 & 0.17 & 8.29 & 2.45 & 1.36 & 1.42 & 0.08 & 99.94 & 6.55 & $\mathrm{a}$ \\
\hline $70 \mathrm{R}-3,2-5 \mathrm{~cm}$ & 41.8 & 51.27 & 1.21 & 15.57 & 12.03 & 0.21 & 7.18 & 9.87 & 2.12 & 0.40 & 0.08 & 99.95 & 2.46 & $\mathrm{a}$ \\
\hline $70 \mathrm{R}-4,0-8 \mathrm{~cm}$ & 42.0 & 50.60 & 1.23 & 15.49 & 12.84 & 0.22 & 7.20 & 9.77 & 2.13 & 0.30 & 0.07 & 99.85 & 5.53 & \\
\hline $70 \mathrm{R}-4,11-26 \mathrm{~cm}$ & 39.6 & 49.69 & 1.20 & 15.76 & 12.42 & 0.21 & 6.78 & 10.89 & 2.59 & 0.23 & 0.10 & 99.87 & 4.22 & $\mathrm{~b}$ \\
\hline $70 \mathrm{R}-4,108-113 \mathrm{~cm}$ & 48.2 & 51.68 & 1.11 & 15.21 & 13.83 & 0.22 & 8.31 & 7.28 & 1.63 & 0.55 & 0.06 & 99.88 & 12.37 & $\mathrm{~b}$ \\
\hline $71 \mathrm{R}-2,105-107 \mathrm{~cm}$ & 47.1 & 50.04 & 1.22 & 18.24 & 10.48 & 0.16 & 7.95 & 8.55 & 2.97 & 0.23 & 0.10 & 99.93 & 2.69 & $\mathrm{a}$ \\
\hline $71 \mathrm{R}-2,110-124 \mathrm{~cm}$ & 50.2 & 49.75 & 1.15 & 18.48 & 11.11 & 0.18 & 8.52 & 7.40 & 2.93 & 0.28 & 0.09 & 99.88 & 9.85 & $\mathrm{~b}$ \\
\hline $71 \mathrm{R}-2,124-130 \mathrm{~cm}$ & 48.3 & 49.98 & 1.23 & 18.43 & 10.66 & 0.16 & 7.94 & 8.07 & 3.02 & 0.26 & 0.10 & 99.86 & 8.83 & \\
\hline $71 \mathrm{R}-3,125-127 \mathrm{~cm}$ & 67.6 & 56.02 & 1.08 & 16.86 & 15.31 & 0.19 & 5.25 & 2.44 & 1.14 & 1.66 & 0.02 & 99.95 & 8.12 & $\mathrm{a}$ \\
\hline $72 \mathrm{R}-1,10-12 \mathrm{~cm}$ & 56.3 & 50.71 & 1.66 & 18.33 & 12.09 & 0.28 & 8.31 & 5.09 & 2.83 & 0.53 & 0.11 & 99.93 & 5.13 & $\mathrm{a}$ \\
\hline $72 \mathrm{R}-2,0-12 \mathrm{~cm}$ & 49.8 & 49.09 & 1.55 & 16.50 & 13.31 & 0.39 & 8.91 & 6.15 & 3.20 & 0.49 & 0.13 & 99.71 & 10.19 & \\
\hline $73 \mathrm{R}-1,5-15 \mathrm{~cm}$ & 39.8 & 50.35 & 1.16 & 15.29 & 11.92 & 0.14 & 7.75 & 10.38 & 2.65 & 0.13 & 0.08 & 99.85 & 5.37 & \\
\hline 73R-1, 76-79 cm & 40.3 & 50.96 & 1.22 & 15.27 & 11.50 & 0.16 & 7.84 & 9.97 & 2.72 & 0.22 & 0.09 & 99.93 & 1.85 & $\mathrm{a}$ \\
\hline $73 \mathrm{R}-4,25-28 \mathrm{~cm}$ & 37.9 & 50.78 & 1.16 & 14.86 & 11.36 & 0.26 & 7.59 & 11.00 & 2.71 & 0.10 & 0.10 & 99.92 & 0.95 & $\mathrm{a}$ \\
\hline $73 \mathrm{R}-4,62-78 \mathrm{~cm}$ & 38.4 & 50.62 & 1.16 & 15.33 & 10.87 & 0.25 & 7.51 & 11.14 & 2.76 & 0.06 & 0.10 & 99.80 & 4.53 & $\mathrm{~b}$ \\
\hline $73 \mathrm{R}-4,78-83 \mathrm{~cm}$ & 38.0 & 50.64 & 1.18 & 15.24 & 10.98 & 0.25 & 7.34 & 11.22 & 2.80 & 0.07 & 0.10 & 99.83 & 4.20 & \\
\hline $74 \mathrm{R}-1,53-55 \mathrm{~cm}$ & 37.7 & 50.75 & 1.01 & 13.63 & 12.81 & 0.30 & 8.56 & 10.15 & 2.47 & 0.20 & 0.08 & 99.95 & 1.65 & $\mathrm{a}$ \\
\hline $74 \mathrm{R}-1,80-91 \mathrm{~cm}$ & 38.2 & 50.52 & 1.16 & 15.08 & 11.32 & 0.25 & 7.39 & 11.12 & 2.67 & 0.07 & 0.10 & 99.69 & 4.19 & \\
\hline $74 \mathrm{R}-1,120-132 \mathrm{~cm}$ & 38.1 & 50.61 & 1.20 & 14.90 & 11.38 & 0.25 & 7.46 & 11.05 & 2.63 & 0.07 & 0.12 & 99.67 & 4.40 & $\mathrm{~b}$ \\
\hline $74 \mathrm{R}-2,19-21 \mathrm{~cm}$ & 38.2 & 50.79 & 1.20 & 15.31 & 11.00 & 0.28 & 7.17 & 11.23 & 2.74 & 0.07 & 0.11 & 99.90 & 1.13 & $\mathrm{a}$ \\
\hline $74 \mathrm{R}-2,76-85 \mathrm{~cm}$ & 37.9 & 48.80 & 1.10 & 14.11 & 15.07 & 0.27 & 7.17 & 10.56 & 2.46 & 0.17 & 0.11 & 99.82 & 2.74 & \\
\hline $74 \mathrm{R}-3,17-19 \mathrm{~cm}$ & 43.2 & 49.49 & 1.34 & 16.82 & 11.55 & 0.21 & 7.70 & 9.35 & 3.11 & 0.20 & 0.10 & 99.88 & 2.43 & $\mathrm{a}$ \\
\hline $75 \mathrm{R}-3,52-54 \mathrm{~cm}$ & 91.5 & 43.52 & 2.07 & 31.70 & 19.92 & 0.07 & 0.71 & 1.27 & 0.43 & 0.10 & 0.07 & 99.86 & 10.06 & $\mathrm{a}$ \\
\hline
\end{tabular}


Table 1

Continued

\begin{tabular}{|c|c|c|c|c|c|c|c|c|c|c|c|c|c|c|}
\hline Sample interval & CIA & $\mathrm{SiO}_{2}$ & $\mathrm{TiO}_{2}$ & $\mathrm{Al}_{2} \mathrm{O}_{3}$ & $\mathrm{Fe}_{2} \mathrm{O}_{3}{ }^{*}$ & $\mathrm{MnO}$ & $\mathrm{MgO}$ & $\mathrm{CaO}$ & $\mathrm{Na}_{2} \mathrm{O}$ & $\mathrm{K}_{2} \mathrm{O}$ & $\mathrm{P}_{2} \mathrm{O}_{5}$ & Total & LOI & Ref. \\
\hline $75 \mathrm{R}-4,98-100 \mathrm{~cm}$ & 84.7 & 39.18 & 2.63 & 27.36 & 26.42 & 0.30 & 0.88 & 2.03 & 0.61 & 0.35 & 0.05 & 99.81 & 11.01 & $\mathrm{a}$ \\
\hline $75 \mathrm{R}-7,65-67 \mathrm{~cm}$ & 72.8 & 50.33 & 2.30 & 21.28 & 17.66 & 0.17 & 2.44 & 2.84 & 1.02 & 1.58 & 0.25 & 99.87 & 8.05 & $\mathrm{a}$ \\
\hline $75 \mathrm{R}-7,126-128 \mathrm{~cm}$ & 61.1 & 49.47 & 2.35 & 18.99 & 14.23 & 0.55 & 6.20 & 3.61 & 2.70 & 1.54 & 0.24 & 99.89 & 6.34 & $\mathrm{a}$ \\
\hline \multicolumn{15}{|l|}{ (b) Hole U1513E } \\
\hline $2 \mathrm{R}-4,25-35 \mathrm{~cm}$ & 48.2 & 47.52 & 0.53 & 19.54 & 9.69 & 0.10 & 10.45 & 9.50 & 2.30 & 0.03 & 0.06 & 99.71 & 9.14 & \\
\hline $2 \mathrm{R}-4,60-69 \mathrm{~cm}$ & 46.4 & 48.44 & 0.59 & 17.72 & 9.34 & 0.13 & 11.38 & 8.97 & 2.42 & 0.25 & 0.04 & 99.29 & 8.12 & \\
\hline $2 \mathrm{R}-5,77-87 \mathrm{~cm}$ & 45.4 & 49.09 & 0.51 & 18.07 & 8.30 & 0.16 & 11.20 & 9.96 & 2.21 & 0.10 & 0.04 & 99.63 & 5.38 & \\
\hline $2 \mathrm{R}-6,50-52 \mathrm{~cm}$ & 45.6 & 48.74 & 0.58 & 18.61 & 8.63 & 0.16 & 10.66 & 10.08 & 2.38 & 0.10 & 0.05 & 100.0 & 6.42 & \\
\hline $2 \mathrm{R}-8,20-22 \mathrm{~cm}$ & 81.0 & 49.90 & 0.76 & 27.93 & 13.49 & 0.11 & 3.74 & 2.12 & 1.20 & 0.73 & 0.02 & 100.0 & 20.15 & \\
\hline $2 \mathrm{R}-8,20-22 \mathrm{~cm}$ & 79.3 & 50.05 & 0.72 & 27.17 & 13.22 & 0.11 & 3.57 & 2.20 & 1.41 & 0.70 & 0.00 & 99.15 & 8.90 & \\
\hline $2 \mathrm{R}-8,95-109 \mathrm{~cm}$ & 56.1 & 47.54 & 0.62 & 22.73 & 8.44 & 0.28 & 9.98 & 7.73 & 2.17 & 0.22 & 0.04 & 99.75 & 14.79 & \\
\hline $3 \mathrm{R}-1,30-32 \mathrm{~cm}$ & 72.3 & 46.47 & 0.65 & 26.89 & 9.41 & 0.20 & 9.63 & 4.20 & 1.31 & 0.47 & 0.00 & 99.23 & 6.50 & \\
\hline $3 \mathrm{R}-2,30-32 \mathrm{~cm}$ & 92.2 & 39.31 & 2.35 & 31.56 & 23.99 & 0.06 & 1.04 & 0.83 & 0.61 & 0.22 & 0.03 & 100.0 & 14.13 & \\
\hline $3 \mathrm{R}-2,30-32 \mathrm{~cm}$ & 87.0 & 38.63 & 2.25 & 30.44 & 23.42 & 0.06 & 1.02 & 1.05 & 1.46 & 0.23 & 0.00 & 98.56 & 8.20 & \\
\hline $3 \mathrm{R}-5,30-32 \mathrm{~cm}$ & 82.3 & 43.74 & 1.28 & 28.84 & 17.72 & 0.10 & 2.61 & 1.91 & 1.01 & 1.09 & 0.05 & 98.35 & 10.80 & \\
\hline $3 \mathrm{R}-6,65-70 \mathrm{~cm}$ & 84.5 & 45.69 & 1.37 & 28.00 & 10.14 & 0.20 & 11.12 & 1.60 & 1.07 & 0.46 & 0.01 & 99.65 & 21.59 & \\
\hline $3 \mathrm{R}-7,130-132 \mathrm{~cm}$ & 87.6 & 33.00 & 2.02 & 22.93 & 38.95 & 0.07 & 0.78 & 1.25 & 0.63 & 0.23 & 0.13 & 100.0 & 13.33 & \\
\hline $5 \mathrm{R}-3,81-88 \mathrm{~cm}$ & 43.8 & 50.53 & 1.29 & 17.25 & 10.11 & 0.16 & 7.76 & 9.58 & 2.93 & 0.13 & 0.10 & 99.84 & 7.02 & \\
\hline $5 \mathrm{R}-4,53-55 \mathrm{~cm}$ & 60.0 & 53.43 & 0.98 & 15.08 & 14.31 & 0.17 & 9.73 & 3.25 & 1.89 & 1.07 & 0.05 & 99.95 & 14.80 & \\
\hline $5 \mathrm{R}-4,93.5-104 \mathrm{~cm}$ & 56.8 & 50.93 & 1.26 & 16.61 & 13.61 & 0.17 & 9.74 & 4.39 & 2.53 & 0.58 & 0.06 & 99.88 & 15.79 & \\
\hline $6 \mathrm{R}-2,100-112 \mathrm{~cm}$ & 53.7 & 49.95 & 1.59 & 16.93 & 13.89 & 0.25 & 8.45 & 5.37 & 2.75 & 0.54 & 0.12 & 99.85 & 13.45 & \\
\hline $6 \mathrm{R}-3,2-4 \mathrm{~cm}$ & 64.1 & 52.58 & 1.32 & 16.75 & 16.91 & 0.13 & 6.48 & 3.13 & 1.82 & 0.80 & 0.08 & 100.0 & 17.93 & \\
\hline $6 \mathrm{R}-5,9.5-22.5 \mathrm{~cm}$ & 45.7 & 50.18 & 1.25 & 17.08 & 11.41 & 0.30 & 7.90 & 8.60 & 2.74 & 0.34 & 0.10 & 99.89 & 8.55 & \\
\hline $6 \mathrm{R}-6,36.8-46 \mathrm{~cm}$ & 56.4 & 49.05 & 1.43 & 18.03 & 14.60 & 0.44 & 7.85 & 5.27 & 2.22 & 0.88 & 0.10 & 99.87 & 13.84 & \\
\hline $6 \mathrm{R}-6,54-56 \mathrm{~cm}$ & 58.2 & 49.64 & 1.55 & 18.72 & 14.07 & 0.49 & 7.30 & 5.10 & 2.07 & 0.96 & 0.11 & 100.0 & 12.16 & \\
\hline $6 \mathrm{R}-7,45-47 \mathrm{~cm}$ & 68.7 & 49.47 & 1.34 & 18.47 & 17.45 & 0.47 & 7.15 & 2.70 & 0.95 & 1.93 & 0.06 & 100.0 & 16.98 & \\
\hline 7R-1, 67-69 cm & 90.3 & 43.69 & 2.02 & 32.17 & 18.92 & 0.09 & 0.94 & 1.29 & 0.70 & 0.12 & 0.07 & 100.0 & 16.76 & \\
\hline $7 \mathrm{R}-3,110-112 \mathrm{~cm}$ & 96.4 & 45.77 & 1.95 & 39.60 & 11.14 & 0.04 & 0.43 & 0.54 & 0.33 & 0.13 & 0.08 & 100.0 & 13.17 & \\
\hline $7 \mathrm{R}-3,110-112 \mathrm{~cm}$ & 95.5 & 46.64 & 1.89 & 38.81 & 10.24 & 0.04 & 0.40 & 0.54 & 0.53 & 0.13 & 0.07 & 99.29 & 8.80 & \\
\hline $7 \mathrm{R}-5,19-21 \mathrm{~cm}$ & 90.2 & 39.89 & 2.45 & 31.40 & 23.08 & 0.23 & 0.65 & 1.18 & 0.71 & 0.31 & 0.10 & 100.0 & 15.44 & \\
\hline $7 \mathrm{R}-8,54-56 \mathrm{~cm}$ & 81.6 & 43.62 & 2.69 & 25.49 & 22.62 & 0.25 & 1.59 & 1.88 & 0.88 & 0.93 & 0.05 & 100.0 & 15.89 & \\
\hline $7 \mathrm{R}-8,56-58 \mathrm{~cm}$ & 79.9 & 44.08 & 2.51 & 25.31 & 21.41 & 0.25 & 1.54 & 2.11 & 1.05 & 0.83 & 0.04 & 99.13 & 7.40 & \\
\hline $8 \mathrm{R}-1,74-76 \mathrm{~cm}$ & 76.5 & 46.22 & 2.01 & 23.80 & 20.50 & 0.12 & 2.01 & 2.31 & 1.24 & 0.99 & 0.00 & 99.20 & 7.40 & \\
\hline $8 \mathrm{R}-3,55-57 \mathrm{~cm}$ & 69.9 & 51.61 & 1.79 & 19.70 & 17.28 & 0.18 & 2.89 & 2.59 & 1.31 & 2.00 & 0.23 & 99.58 & 8.90 & \\
\hline $8 \mathrm{R}-3,138-140 \mathrm{~cm}$ & 64.0 & 47.45 & 1.91 & 18.51 & 19.26 & 0.37 & 5.28 & 3.74 & 0.92 & 2.36 & 0.19 & 100.0 & 16.26 & \\
\hline $8 \mathrm{R}-4,94-96 \mathrm{~cm}$ & 50.6 & 48.80 & 2.01 & 19.71 & 10.89 & 0.48 & 6.56 & 7.34 & 3.66 & 0.34 & 0.21 & 100.0 & 5.43 & \\
\hline $8 \mathrm{R}-4,114-118 \mathrm{~cm}$ & 51.2 & 47.95 & 2.04 & 19.60 & 11.25 & 0.46 & 7.31 & 7.06 & 3.67 & 0.27 & 0.21 & 99.82 & 6.32 & $\mathrm{~b}$ \\
\hline $9 \mathrm{R}-1,120-122 \mathrm{~cm}$ & 55.5 & 52.26 & 1.74 & 16.55 & 13.89 & 0.29 & 6.78 & 5.18 & 1.61 & 1.46 & 0.16 & 99.93 & 13.00 & \\
\hline $9 \mathrm{R}-2,6-10 \mathrm{~cm}$ & 59.2 & 52.08 & 1.87 & 16.76 & 15.25 & 0.30 & 5.90 & 4.21 & 1.27 & 2.05 & 0.18 & 99.88 & 17.16 & \\
\hline 9R-4, 88-103 cm & 49.9 & 49.67 & 1.22 & 20.04 & 10.36 & 0.25 & 6.43 & 8.06 & 3.11 & 0.58 & 0.12 & 99.84 & 7.82 & \\
\hline $9 \mathrm{R}-5,29-42 \mathrm{~cm}$ & 55.5 & 52.30 & 1.74 & 16.56 & 13.89 & 0.29 & 6.79 & 5.19 & 1.61 & 1.46 & 0.16 & 100.0 & 13.06 & \\
\hline
\end{tabular}

Note. CIA values were calculated using molar amounts of oxides and corrected $\mathrm{CaO}$ contents. The values with lithologic unit and lithology are presented in Figure $5 \mathrm{a}$. $\mathrm{Fe}_{2} \mathrm{O}_{3}$ * is total $\mathrm{Fe}$ as $\mathrm{Fe}_{2} \mathrm{O}_{3}$. LOI represents loss on ignition (\%). Reference indicates archived XRF data compiled from PANGAEA websites (a) https:// doi.org/10.1594/PANGAEA.924535 and (b) https://doi.org/10.1594/PANGAEA.933955. 
Chemical Index of Alteration (CIA), which is a sensitive measure of alteration intensity. According to Pola et al. (2012), values of CIA are well correlated with the degradation trend exhibited by petrophysical properties. CIA has been used to identify weathering degree in volcanic provinces (e.g., Babechuk et al., 2014; Le Blond et al., 2015; Pola et al., 2014). Thus, we select CIA as a quantitative tool to evaluate the alteration intensity. It is quantified as (Nesbitt \& Young, 1982);

$$
\mathrm{CIA}=\frac{\mathrm{Al}_{2} \mathrm{O}_{3}}{\mathrm{Al}_{2} \mathrm{O}_{3}+\mathrm{CaO}^{*}+\mathrm{Na}_{2} \mathrm{O}+\mathrm{K}_{2} \mathrm{O}} \times 100
$$

where $\mathrm{Al}_{2} \mathrm{O}_{3}, \mathrm{CaO}, \mathrm{Na}_{2} \mathrm{O}$, and $\mathrm{K}_{2} \mathrm{O}$ are molar values. The molar $\mathrm{CaO}$ is corrected for the presence of apatite by subtracting 1.312 times the amount of $\mathrm{P}_{2} \mathrm{O}_{5}$ to represent Ca silicate-bearing minerals only (CaO*; Fedo et al., 1995). CIA values of 82 samples are presented in Table 1. Based on qualitative alteration descriptions (Tejada et al., 2020), we establish CIA to indicate four ranges of alteration intensity: fresh-slight (CIA 3540), weak (CIA 40-60), moderate (CIA 60-80), strong (CIA 80-100). CIA values of standard basalt samples (USGS Hawaiian basalt BHVO-2) are between 35 and 36. Due to low $\mathrm{K}_{2} \mathrm{O}$ content ( $0.5 \mathrm{wt} \%$ on average) in the volcanic sequence at Site U1513, the values and alteration range are similar with those from other chemical weathering indices such as Chemical Index of Weathering (CIW; Harnois, 1988) and Plagioclase Index of Alteration (PIA; Fedo et al., 1995). In addition to the index value, the proportional changes of the major elements $\left(\mathrm{Al}_{2} \mathrm{O}_{3}, \mathrm{CaO}^{*}+\mathrm{Na}_{2} \mathrm{O}+\mathrm{K}_{2} \mathrm{O}, \mathrm{FeO}+\mathrm{MgO}\right)$ are shown graphically with the A-CNK-FM ternary plot (Nesbitt \& Young, 1989).

\section{Lithologic Description and Alteration Degree}

The volcanic sequence lies below an erosional contact with volcaniclastic-rich sequence (Lithostratigraphic Unit V). It can be subdivided into five flow packages or lithologic units (Units 1, 3, 5, 7, and 9), separated by volcaniclastic beds (Units 2, 4, 6, and 8). Each flow package consists of one to several discrete lava flows that are variably bounded by chilled margins, fragmented intervals, brecciated flow tops, or gradational textural changes (Tejada et al., 2020). The alteration of the volcanic rocks varies from fresh-slight to strong intensity, indicated by color, textural and fabric changes, secondary mineralization, and CIA values (Figures 2b, 3, 4 and 5a). Replacement of igneous mineral phenocrysts and groundmass by secondary minerals, as well as vesicle and vein fillings, occur throughout the basalt series. Alteration ranges from smectite-chlorite replacement of primary minerals and groundmass and devitrification of volcanic glass (if present) in slightly to weakly altered intervals to calcite veining, chloritization \pm vermiculite, \pm kaolinite, and hematization in moderately to strongly altered rocks (Figures 3a and 4; Riquier et al., 2021; Tejada et al., 2020). There is a proportional relationship between increasing alteration intensity and enhanced formation of clay minerals such as smectite, chlorite, vermiculite, and kaolinite that represent the alteration products of Ca-Na-rich feldspar, glass, and mafic minerals such as pyroxenes and olivine (Figure $3 b$ ). The quantified alteration intensity using CIA values (Table 1, Figure 5a) corresponds to changes in lithologic characteristics and increasing amount of secondary minerals.

Here we summarize the distinct lithologic and alteration characteristics of each unit (Figures 2 and 3) that are correlative to petrophysical variations. For detailed descriptions and mineralogical composition, we refer the reader to Tejada et al. (2020) and Riquier et al. (2021). Unit 1 and Unit 3 are each composed of a greenish gray, thick, non- to sparsely (1\%-3\%) vesicular massive flow with large plagioclase (1-3 cm long), together with pyroxene \pm olivine as phenocrysts, in a fine-grained groundmass. In Hole E, the two units are separated by Unit 2, which is a structureless volcaniclastic flow with pebble- to granule-sized basalt clasts and kaolinized plagioclase grains in poorly sorted and highly altered matrix (CIA $=79-81$ ). Unit 1 is weakly altered except near the top and bottom of the flow. Olivine is mostly altered to serpentine and the groundmass pyroxene is replaced by chlorite and smectite (CIA $=45-49)$. It is more altered near the base of the unit, where it is cut by several $\leq 1 \mathrm{~cm}$ thick calcite veins (see Unit 1 in Figure 2b). Unit 3 is intruded by a dolerite dike, resulting in higher degree of alteration than Unit 1 . Alteration occurs as calcite veining and partial recrystallization of groundmass in addition to chlorite-smectite formation and serpentinization $(\mathrm{CIA}=47-72)$. The bottom half is reddish colored due to replacement of groundmass by hematite that become pervasive toward the irregular, baked contact with Unit 4. 
a) Thin section images
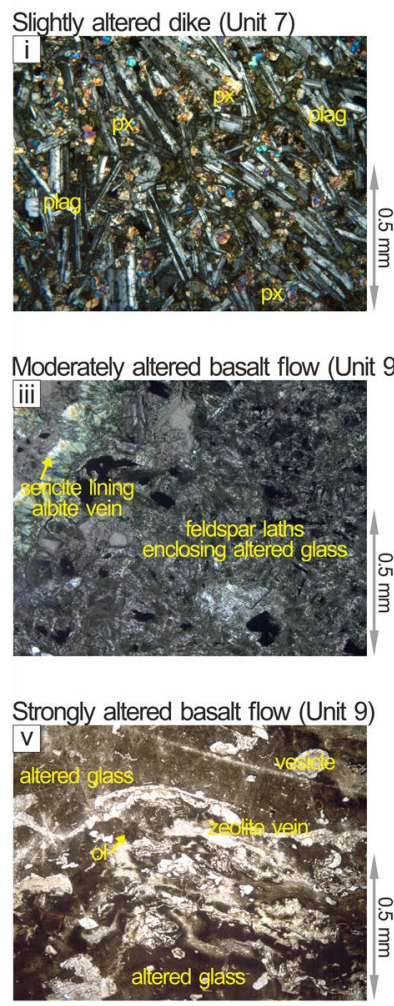

Weakly altered basalt flow (Unit 3)
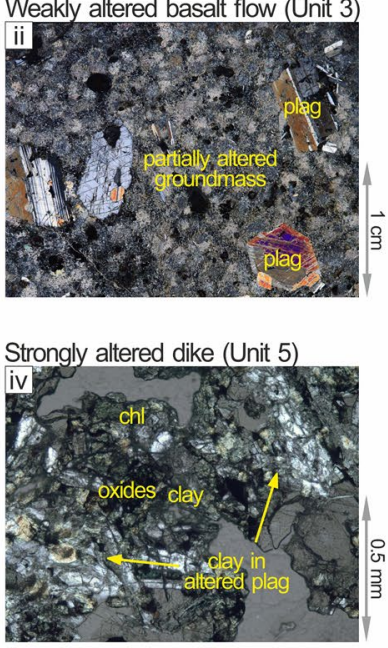

Strongly altered volcaniclastics (Unit 8)

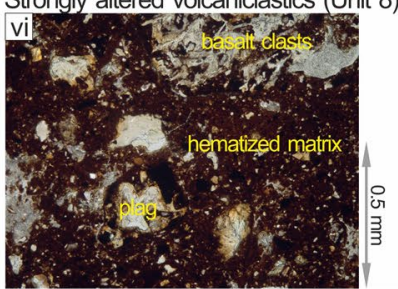

b) A-CNK-FM plot

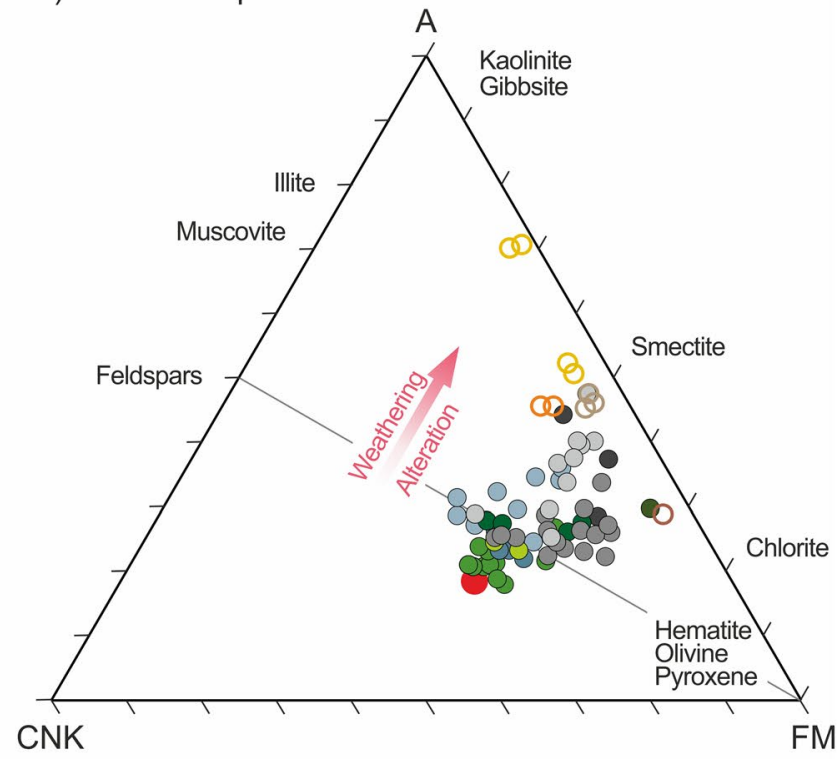

\begin{tabular}{|ccc|}
\hline Basalt flow & Dike & Volcaniclastics \\
Unit 1 & 0 in Unit 3 & 0 Unit 2 \\
Unit 3 & 0 in Unit 5 & 0 Unit 4 \\
Unit 5 & 0 in Unit 7 & 0 Unit 6 \\
Unit 7 & 0 in Unit 9 & 0 Unit 8 \\
Unit 9 & Basalt standard & \\
\hline
\end{tabular}

Figure 3. (a) Representative thin section images of each alteration intensity from Holes D and E, showing petrographic details; (i) Slightly altered finegrained dolerite dike with pyroxene and plagioclase (Unit 7; U1513D-73R-5, 141-145 cm). (ii) Weakly altered basalt with large plagioclase and partially altered groundmass (Unit 3; U1513D-67R-1, 25.5-28.5 cm). (iii) Moderately altered basalt with relict texture of feldspar laths, partially altered groundmass, and sericite lining albite vein (Unit 9; U1513D-75R-7, 65-67 cm). (iv) Strongly altered basalt showing clay in altered plagioclases, chlorite, and oxides (Unit 5; U1513D68R-1, 28-30 cm). (v) Strongly altered basalt showing zeolite vein, stretched amygdule, altered glass, and partially altered olivine (Unit 9; U1513D-75R-4, 98-100 cm). (vi) Strongly altered volcaniclastics showing basalt clasts, plagioclase, and hematized matrix (Unit 8; U1513D-67R-4, 28-31 cm). (b) A-CNK-FM ternary plot for the basalt flow, dike, and volcaniclastic rocks recovered from the volcanic sequence at Site U1513. The molar ratios of the major element oxides $\left(\mathrm{Al}_{2} \mathrm{O}_{3}, \mathrm{CaO}^{*}+\mathrm{Na}_{2} \mathrm{O}+\mathrm{K}_{2} \mathrm{O}, \mathrm{FeO}+\mathrm{MgO}\right)$ are used by converting the wt.\% concentrations into moles. Position of standard basalt sample (USGS Hawaiian basalt BHVO-2) is presented (large red dot).

Unit 4 is an extensively hematized massive volcaniclastic flow (CIA $=87-92$; Figure $4 \mathrm{e}$ ) with four clastrich intervals and displays a gradational boundary with underlying strongly altered basalt flows. Unit 5 is a compound flow, consisting of strongly to completely altered flows with flow banding structure (see Unit 5 in Figure $2 \mathrm{~b}$ ). The upper $\sim 3 \mathrm{~m}$ is composed of thin lobes (7-12 cm thick) of aphyric, vesicular (10\%-15\% vesicles/amygdules) basalts, with curved chilled margins, concentric alteration haloes, and occasional radial cracks. Altered hyaloclastites and volcaniclastic matrix fill the spaces between the flow lobes. These lobate flows are brown to reddish brown, indicating complete transformation of primary minerals to chlorite, serpentine, kaolinite and goethite \pm hematite (CIA $=82-85$ ). An equally altered $\sim 25 \mathrm{~cm}$-wide inclined dike, with dark to light brown chilled margins, crosscuts this unit. Its green-gray color indicates replacement of most primary minerals by chlorite \pm vermiculite and smectite (CIA $=86$; see Unit 5 in Figures 3a and 4d). The lower half consists of brown-gray, thicker and massive flow that is moderately altered (CIA = 70), except for the highly altered top and bottom, and still contains primary plagioclase phenocrysts in microcrystalline groundmass. The flow bottom is marked by a baked, red band chilled margin. Unit 6 is a thin interflow volcaniclastic breccia that is strongly altered and replaced by kaolinite, undifferentiated clays and hematite (CIA = 88). It grades downward to the trachytic, vesicular, and oxidized top of a strongly altered flow of Unit 7.

Unit 7 and Unit 9 are similar in having several plagioclase \pm pyroxene-phyric basalts forming massive flows that grade into thinner aphyric, vesicular to amygdaloidal flows toward the top. Unit 7 is a thick compound flow (40.65 $\mathrm{m}$ thick in Hole E) consisting of at least four lava flows. The flow boundaries are indicated 
a) Slight alteration

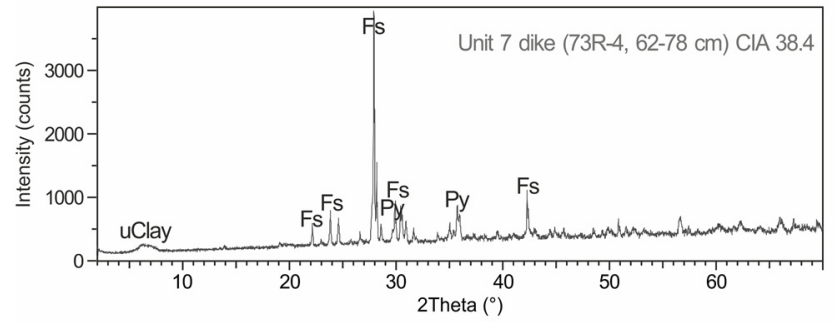

b) Weak alteration

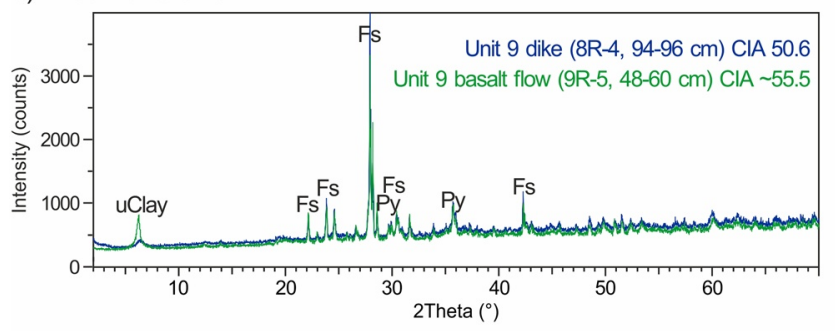

Clay fraction analysis (Mg-glycerol saturation)

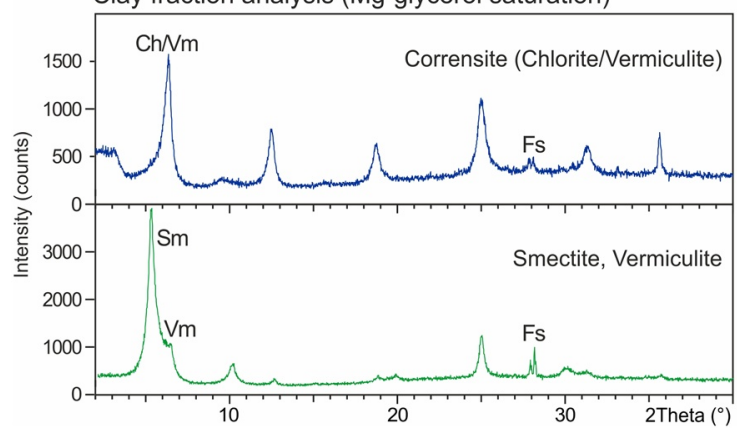

c) Moderate alteration

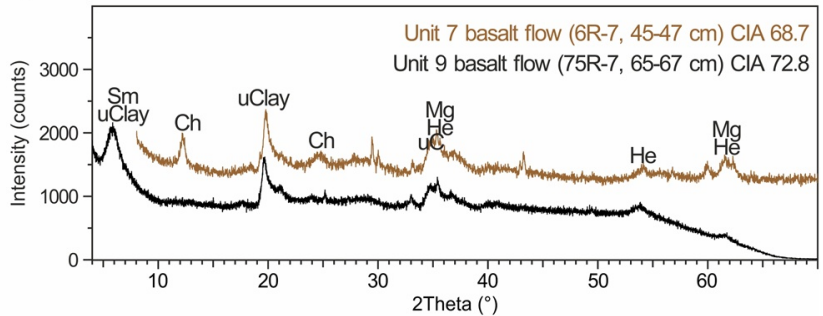

d) Strong alteration (basalt)

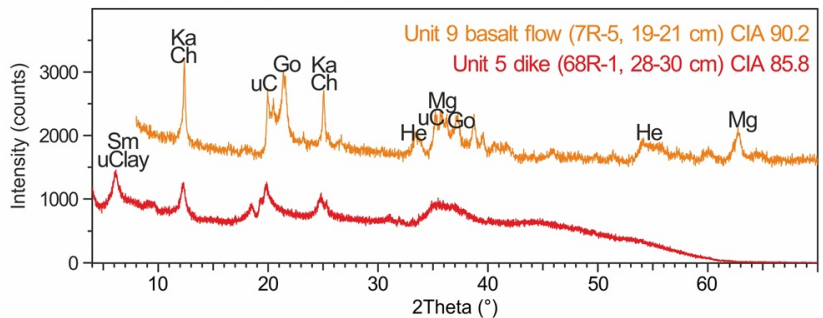

e) Strong alteration (volcaniclastics)

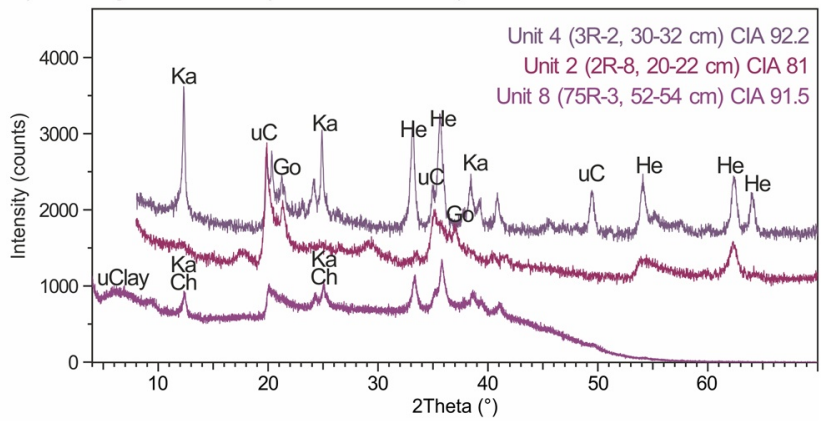

Figure 4. X-ray diffraction (XRD) mineralogical identification for each alteration intensity and lithology. (a) Slightly altered dolerite dike of Unit 7 (U1513D73R-4, 62-78 cm; Chemical Index of Alteration [CIA] 38.4). (b) Weakly altered dike (U1513E-8R-4, 94-96 cm; CIA 50.6) and basalt flow (U1513E-9R-5, 48-60 cm; CIA 55.5) of Unit 9. XRD patterns of Mg-glycerol saturated clay fraction of the samples. (c) Moderately altered basalt flows of Unit 7 (U1513E-6R-7, 45-47 cm; CIA 68.7) and Unit 9 (U1513D-75R-7, 65-67 cm; CIA 72.8). (d) Strongly altered basalt flow of Unit 9 (U1513E-7R-5, 19-21 cm; CIA 90.2) and dike of Unit 5 (U1513D-68R-1, 26-30 cm; CIA 85.8). (e) Strongly altered volcaniclastic flows of Unit 4 (U1513E-3R-2, 30-32 cm; CIA 92.2), Unit 2 (U1513E-2R-8, 20-22 cm; CIA 81) and Unit 8 (U1513D-75R-3, 52-54 cm; CIA 91.5). uClay: undifferentiated clays, Fs: feldspar, Py: pyroxene, Ch: chlorite, Vm: vermiculite, Sm: smectite, Mg: magnetite, He: hematite, Ka: kaolinite, Go: goethite.

by moderately altered, vesicular (5\%-10\% vesicles/amygdules) and fragmented intervals with the original glassy matrix partially to completely replaced by hematite $(\mathrm{CIA}=68)$. The vesicles are highly elongated and stretched parallel to flow margins, most of which are filled with clay minerals and zeolite (see Unit 7 basalt flow in Figure $2 \mathrm{~b}$ ). Fresher, sparsely vesicular (1\%-3\% vesicles) and massive interiors are composed of altered olivine-( \pm pyroxene) and plagioclase phenocrysts in intersertal to spherulitic groundmass (CIA $=47-$ 59). The flows are intruded by two relatively fresh, non-vesicular dolerite dikes with large phenocrysts of plagioclase and minor pyroxene \pm olivine (pseudomorphed by serpentine) in fine- to medium-grained groundmass (CIA $=38-40$; see Unit 7 dike in Figures $2 \mathrm{~b}, 3 \mathrm{a}$ and $4 \mathrm{a}$ ). Along the intrusive margins, the dikes are weakly altered (CIA $=40-58$ ) and contain interstratified chlorite-smectite and zeolite, but the flows show a higher degree of alteration with calcite and undifferentiated clays filling veins and vugs, and hematite replacing the groundmass (CIA $=60-69)$. Unit 7 flows are separated from those of Unit 9 by a thick, strongly hematized, poorly sorted, volcaniclastic flow deposit of Unit 8 (CIA = 90-96). The volcaniclastic unit is composed of altered basalt clasts and mineral grains in a fine-grained matrix (see Unit 8 in Figure 2b). It is dominated by kaolinite and hematite with minor chlorite and zeolite (see Unit 8 in Figures 3a and 4e; Riquier et al., 2021). Its bottom boundary appears gradational with Unit 9. Larger clasts display grain orientation layering and interclast matrix diminishes toward the base. Unit 9 consists of several lava flows with highly altered banded or fragmented flow tops that are replaced with chlorite, kaolinite, undifferentiated clays, goethite, magnetite, and hematite (see Unit 9 in Figures 3a and 4). The topmost flow consists 

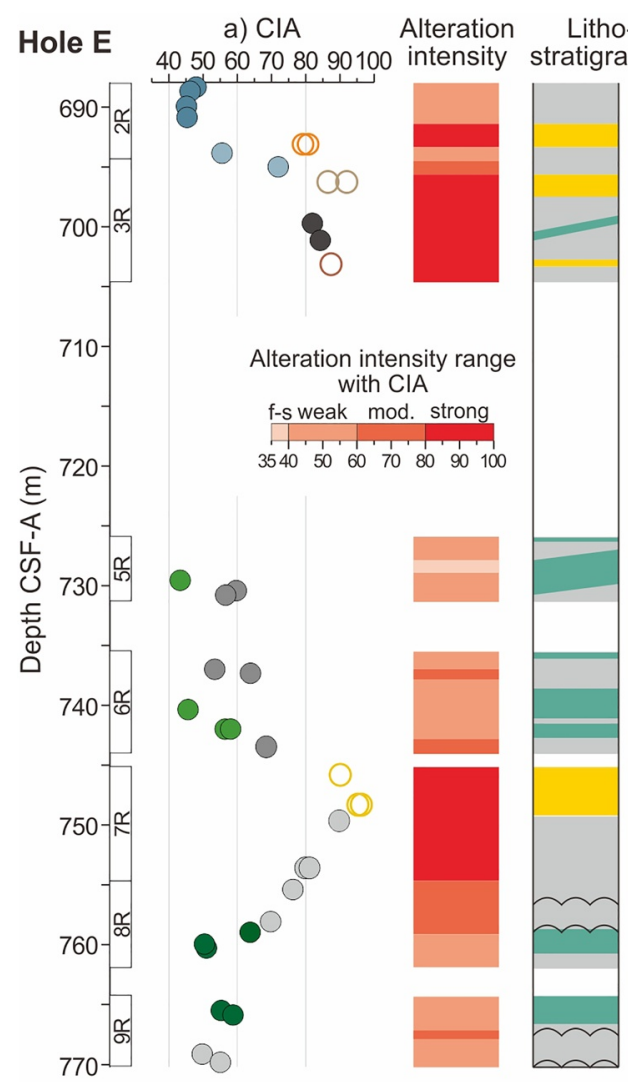

b) Density $\left(\mathrm{g} / \mathrm{m}^{3}\right)$

c) Porosity (\%)

d) Velocity $(\mathrm{m} / \mathrm{s})$

e) TC $(W /(m \cdot K))$


c) Porosity (\%)

d) Velocity $(\mathrm{m} / \mathrm{s})$

e) TC $(W /(m \cdot K))$
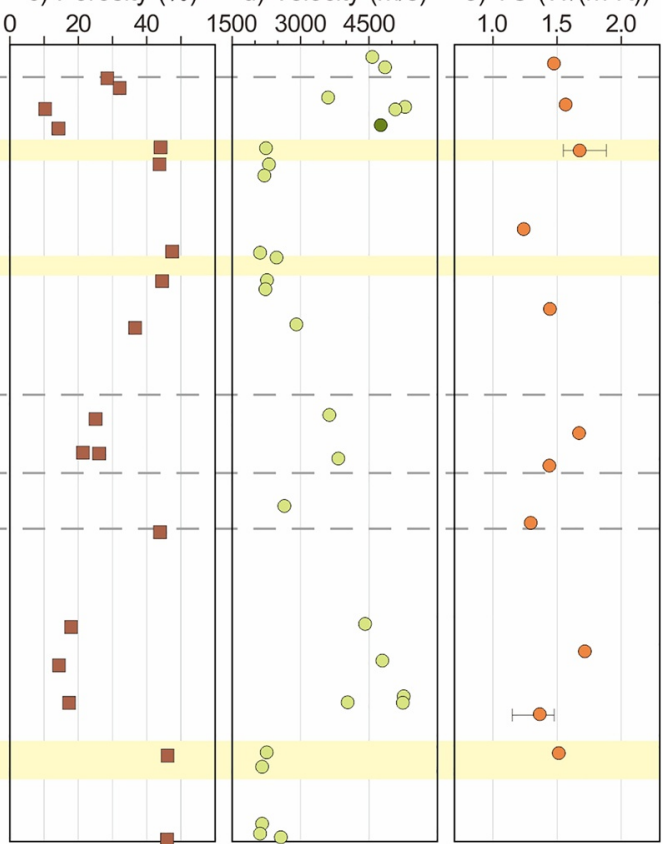

Figure 5.

of strongly altered, highly vesicular ( $20 \%-30 \%$ vesicles) thin lobes (6-15 cm thick) with chilled boundaries or brecciated material (CIA $=82-90$ ), which grades downward into a moderately altered and moderately vesicular (10\%-15\%) massive lava flow with irregular and angular vesicles (CIA = 61-80). These massive flows display flow banding and agglutinated clasts with chilled margins producing patchy, fragmented texture. 
Original glassy matrix is completely replaced by hematite. Toward the end of Hole E, drilling recovered weakly altered dark gray plagioclase \pm pyroxene-phyric sparsely vesicular $(1 \%-5 \%)$ basalts $(\mathrm{CIA}=50-56)$. Alteration in these flows consists of chlorite-smectite and vermiculite (Figure 4b). In Hole E, Unit 9 is also intruded by weakly to moderately altered dikes $(\mathrm{CIA}=51-64)$ that display crisscrossing fractures and microfractures where original groundmass is oxidized and replaced by undifferentiated clays and by hematite and magnetite in more altered intervals.

\section{Petrophysical Property Variations With Alteration Intensity}

\subsection{Grain Density and Bulk Density}

Grain density $\left(\rho_{g}\right)$ of dolerite dikes in the fresh-slight alteration range is $2.8-3.0 \mathrm{~g} / \mathrm{cm}^{3}$ (Figures $5 \mathrm{~b}$ and $6 \mathrm{a}$ ), which conforms to the average grain density of fresh basalts, $\sim 2.9 \mathrm{~g} / \mathrm{cm}^{3}$ (e.g., Christeson et al., 2016; Hyndman \& Drury, 1977). From the fresh-slight to weak alteration range, there is a slight decreasing trend of grain density with CIA. This can be related to increasing clay mineral content (e.g., grain density 2.0-2.6 g/ $\mathrm{cm}^{3}$ of smectite minerals), but the grain density values in the weak alteration range are largely scattered between 2.6 and $3.0 \mathrm{~g} / \mathrm{cm}^{3}$. The moderately to strongly altered rocks show a slight increasing trend of grain density with CIA (Figure $6 \mathrm{a}$ ). One distinct outlier, $\sim 3.3 \mathrm{~g} / \mathrm{cm}^{3}$, is of a highly hematized sample with magnetite (grain density $\sim 5.3 \mathrm{~g} / \mathrm{cm}^{3}$ of hematite and $\sim 5.2 \mathrm{~g} / \mathrm{cm}^{3}$ of magnetite) collected from a dike margin of Unit 9 at Hole $\mathrm{E}$ (Figure $5 \mathrm{~b}$ ). Iron oxides of magnetite and goethite $\left(\sim 3.8 \mathrm{~g} / \mathrm{cm}^{3}\right)$ are present in the strongly altered samples of higher grain density $\left(>2.9 \mathrm{~g} / \mathrm{cm}^{3}\right)$.

The bulk density $\left(\rho_{b}\right)$ calculated from the MAD analysis ranges between 2.0 and $2.7 \mathrm{~g} / \mathrm{cm}^{3}$, while the GRA bulk density values range from $\leq 1.5$ to $2.7 \mathrm{~g} / \mathrm{cm}^{3}$ (Figure $5 \mathrm{~b}$ ). The lower GRA bulk density is introduced by a gap between core section and liner, as well as measurement on fractured and fragmented sections. The bulk density variation over the sequence corresponds well to the lithologic boundaries and alteration intensity distribution (Figures 5a and 5b). Relatively fresh feldspar-rich rocks (e.g., dike in Unit 7, Hole D) have $2.6-2.7 \mathrm{~g} / \mathrm{cm}^{3}$ in the MAD bulk density. With increasing CIA, the bulk density range is $2.2-2.6 \mathrm{~g} / \mathrm{cm}^{3}$ in the weak alteration range (e.g., Unit 1), and mostly $2.0-2.2 \mathrm{~g} / \mathrm{cm}^{3}$ in the moderate alteration range (e.g., near flow boundaries in Unit 7). The strongly altered basalt flows (e.g., Unit 5) show $\sim 2.0 \mathrm{~g} / \mathrm{cm}^{3}$ (Figure $6 \mathrm{~b}$ ). The bulk density $\rho_{b}$ of basalt flows and dikes shows a good correlation with CIA values $\left(R^{2}: 0.73\right)$, following a linear trend equation (Figure 6b);

$$
\rho_{b}=-0.013 \text { CIA }+3.1
$$

The bulk density values of volcaniclastic rocks are scattered and higher than those of strongly altered basalt flows.

\subsection{Porosity}

The slightly altered dikes in Unit 7 show porosity values $(\phi)$ of $6.3 \%-17.9 \%$ (Figure $5 \mathrm{c}$ ), where pore space consists mostly of vesicles and microcracks. This conforms to fresh basalts' porosity of 5\%-10\% and higher in vesicular varieties (e.g., Hyndman \& Drury, 1977; Planke, Cerney, et al., 1999). The porosity values of basalt flows and dikes increase to $50 \%$ with increasing CIA. The strong relation between porosity and CIA is well defined by a linear equation $\left(R^{2}: 0.73\right.$; Figure $\left.6 \mathrm{c}\right)$;

$$
\phi=0.77 \mathrm{CIA}-17
$$

Figure 5. (a) Chemical Index of Alteration (CIA) of the volcanic sequence at Hole E and Hole D (CIA values in Table 1 and color code as in Figure $3 \mathrm{~b}$ ). Lithostratigraphy and core number are presented (from Figure 2a). CSF-A: Core depth below seafloor, Method A. Alteration intensity range (fresh-slight, weak, moderate, strong) is evaluated from CIA values, mineral identification, and macro- and microscopic core descriptions. Petrophysical data through the volcanic sections (revised from Lee \& Song, 2021; Tejada et al., 2020); (b) Bulk and grain density. Bulk density was measured using Gamma Ray Attenuation (GRA) on whole-round core sections ( $2.5 \mathrm{~cm}$ interval) and moisture and density (MAD) analysis on discrete core samples. Grain density was measured using MAD analysis on discrete core samples. (c) Porosity, measured by MAD analysis on discrete core samples. (d) $P$-wave velocity, measured on working-half core sections and discrete core samples. (e) Thermal conductivity (TC), measured on working-half core sections. Averaged values are shown. Locations of volcaniclastic units and flow boundaries are indicated by yellow ranges and gray dashed lines, respectively. 

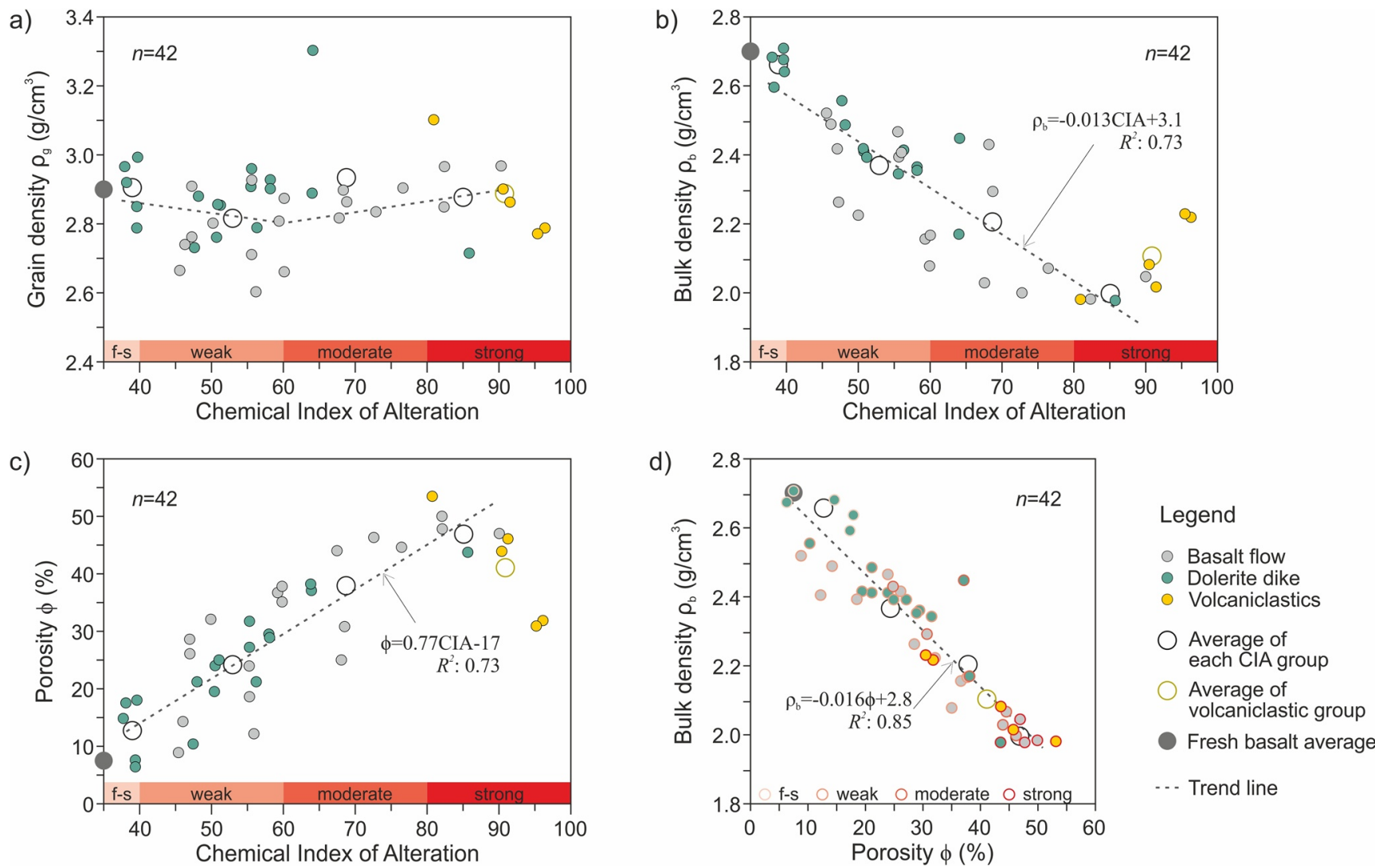

Figure 6. Correlation plots of (a) Grain density versus Chemical Index of Alteration (CIA), (b) Bulk density versus CIA, (c) Porosity versus CIA, (d) Bulk density versus Porosity, with the number $(n)$ of data points and the alteration intensity ranges. Linear trend lines with equation and $R^{2}$ are quantified for data from basalt flows and dikes. Average data point of each alteration range group (black circle), volcaniclastic samples (yellow circle), and fresh basalt from references (large gray dot) are presented for each plot. Grain density, bulk density and porosity are calculated using MAD analysis. Offset between positions of MAD and CIA data is $\leq 30 \mathrm{~cm}$ within individual flows, but a few cases are $>30 \mathrm{~cm}$ based on lithologic description.

In the weakly altered rocks, the porosity values are scattered over a range of $8.8 \%-37.7 \%$. It is typically higher near the margins of basalt flows and dikes (e.g., Unit 3 in Hole D; Figure 5c). The porosity values in the moderate to strong alteration ranges are less scattered, showing an increasing trend from $30 \%$ to $50 \%$ with CIA (Figure 6c). The increase in porosity is correlated well with bulk density decrease (Figure 6d). Since there are minor changes in the grain density with CIA (Figure 6a), the correlation between bulk density and CIA is likely linked to porosity variation. In the altered basalt flows, pore space corresponds to vesicles. Pores were formed by outgassing of magmatic volatiles, autobrecciation, and cooling and quenching fractures. Additionally, secondary pores were created by post-emplacement fracturing and faults, microcracks in alteration minerals, and minor mineral dissolution. The altered rocks contain both primary and secondary pore spaces in general. But the moderately to strongly altered basalt flows showing high porosity are strongly associated with highly vesicular and fragmental textures (Unit 5 and upper flows of Unit 7 and Unit 9). Porosity of the volcaniclastic rocks is largely variable from $30.6 \%$ to $53.5 \%$, which is attributed to primary sedimentary structures, interparticle pore space, and secondary replacement of matrix by hematite. The values follow the trend of bulk density-porosity relation well in Figure 6d.

\section{3. $P$-Wave Velocity}

$P$-wave velocity $\left(V_{P}\right)$ of dikes in the fresh-slight alteration range varies between 4,032 and 5,261 m/s (Figures $5 \mathrm{~d}$ and $7 \mathrm{a}$ ), of which lower values were measured on sections containing xenoliths of porphyritic basalt with diffuse margins. The velocity in the weak alteration range is largely scattered between 5,378 and $2,258 \mathrm{~m} / \mathrm{s}$ (Figure 7a). In general, higher velocity was measured on sections of tight texture showing low 

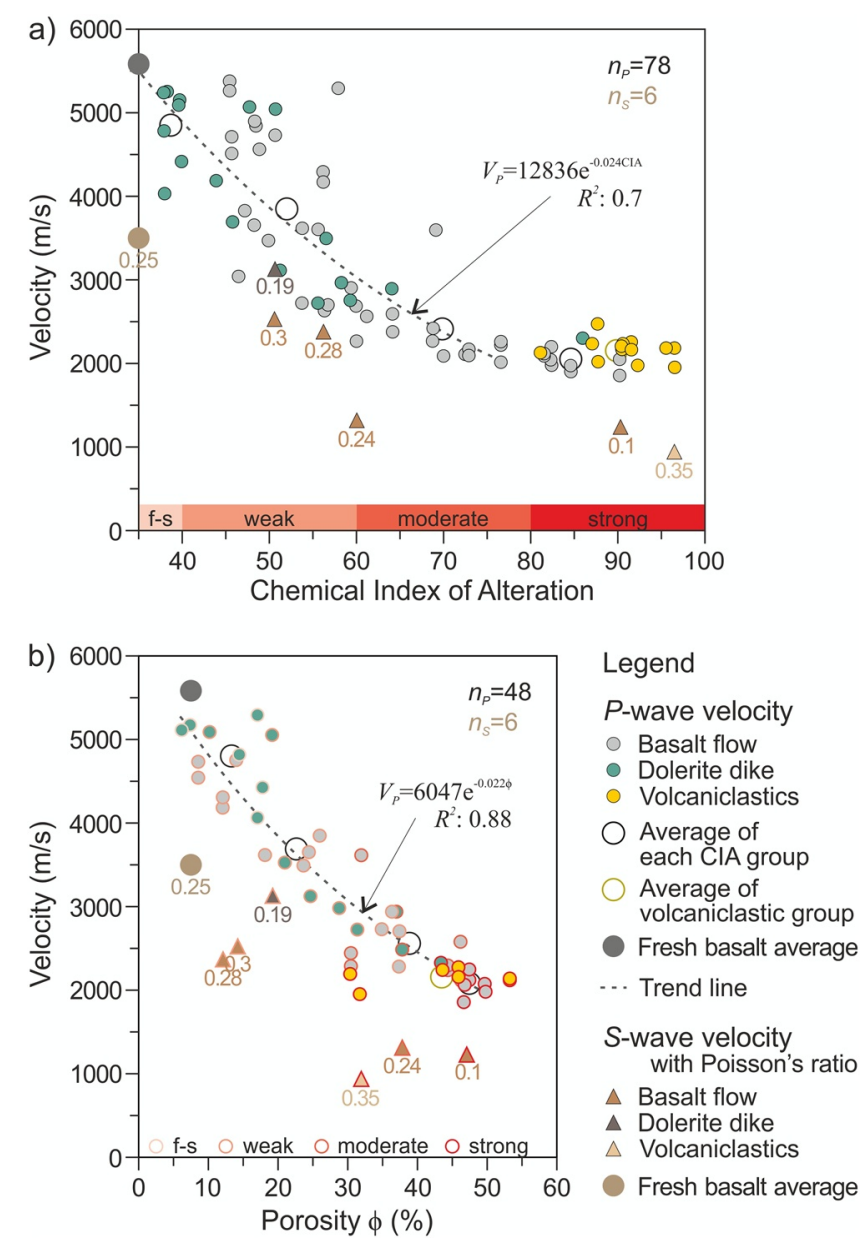

Figure 7. Correlation plots of (a) $P$-wave and $S$-wave velocity versus Chemical Index of Alteration (CIA) and (b) $P$-wave and $S$-wave velocity versus Porosity, with the number $(n)$ of data points and the alteration intensity ranges. $S$-wave velocity is presented with Poisson's ratio. Exponential trend lines with equation and $R^{2}$ are quantified for data from basalt flows and dikes. Average data point of each alteration range group (black circle), volcaniclastic samples (yellow circle), and fresh basalt from references (large gray and brown dots) are presented for each plot. Offset between positions of velocity and CIA data is $\leq 30 \mathrm{~cm}$ within individual flows, but a few cases are $>30 \mathrm{~cm}$ based on lithologic description. vesicularity, often in flow interiors and dikes. The velocity decreases with CIA, which converges exponentially toward CIA 80 where velocity reaches nearly $2,000 \mathrm{~m} / \mathrm{s}$. Its trend can be quantified as (CIA 35-80, $R^{2}: 0.7$ );

$$
V_{P}=12836 \mathrm{e}^{-0.024 \mathrm{CIA}}
$$

The trend line starts from 5,541 m/s at CIA 35, which corresponds to $P$-wave velocity between $\sim 5,490 \mathrm{~m} / \mathrm{s}(\sigma=0.19)$ of plagioclase basalt and $\sim 5,620 \mathrm{~m} / \mathrm{s}(\sigma=0.31)$ of olivine basalt (Schreiber \& Fox, 1977). Both basalts and volcaniclastics in the strong alteration range show $P$-wave velocity near $2,000 \mathrm{~m} / \mathrm{s}$. This is attributed to abundant clay minerals in altered volcanic rocks, which commonly decrease the velocity due to their low elasticity and affinity to water (e.g., Planke, Alvestad, \& Eldholm, 1999). Since the low velocity corresponds to basalt flows of highly vesicular and fragmental texture and at/near flow boundaries, the primary textural condition is an important factor to control the velocity. $S$-wave velocity $\left(V_{S}\right)$ disperses but also decreases from 3,135 to $1,237 \mathrm{~m} / \mathrm{s}$ with CIA (Figure 7a). A sample from strongly altered volcaniclastic flow at Unit 8 shows $934 \mathrm{~m} / \mathrm{s}$. $P$-wave and $S$-wave velocities are tightly correlated $\left(V_{P}=1.66 V_{S}+168, R^{2}: 0.96\right), V_{P} / V_{S}$ ratios of which vary between 1.5 and 1.9 in the basaltic rocks and 2.1 in the volcaniclastic rock (Lee \& Song, 2021). Poisson's ratio $(\nu)$ that is variable between 0.1 and 0.35 does not show a clear relation with CIA. The $P$-wave velocity exponentially decreases with increasing porosity $\left(R^{2}: 0.88\right.$; Figure $\left.7 \mathrm{~b}\right)$;

$$
V_{p}=6047 \mathrm{e}^{-0.022 \phi}
$$

This exponential trend has been reported in previous studies (e.g., Carlson, 2014; Christeson et al., 2016) and is also correlated with decreasing bulk density.

\subsection{Thermal Conductivity}

Thermal conductivity $(\lambda)$ of the slightly altered dike section is $1.72 \mathrm{~W} /$ $(\mathrm{m} \cdot \mathrm{K})$ (Figure $5 \mathrm{e})$, which is similar to the average thermal conductivity of fresh basalts $(\sim 1.7 \mathrm{~W} /(\mathrm{m} \cdot \mathrm{K})$; Hyndman \& Drury, 1977; Mielke et al., 2017). The thermal conductivity decreases linearly to near $1.2 \mathrm{~W} /$ $(\mathrm{m} \cdot \mathrm{K})$ with increasing CIA from the fresh-slight to moderate alteration ranges (Figure 8a). Its trend equation is (CIA 35-80, $R^{2}: 0.69$ );

$$
\lambda=-0.012 \mathrm{CIA}+2.1
$$

In the strongly altered basalt flows, 12 sections were measured for the thermal conductivity, which show variable values between 1.11 and $1.86 \mathrm{~W} /(\mathrm{m} \cdot \mathrm{K})$ (Figure 5e). Eight of them are near $1.2 \mathrm{~W} /(\mathrm{m} \cdot \mathrm{K})$, while four from pervasively hematized sections at Unit 5 and Unit 9 show higher values $\geq 1.43 \mathrm{~W} /(\mathrm{m} \cdot \mathrm{K})$. The values of volcaniclastic rocks are largely scattered over $1.29-2.17 \mathrm{~W} /(\mathrm{m} \cdot \mathrm{K})$, which are also related to hematization degree; the lowest value was measured at Unit 2, while the highest value was measured at the highly hematized interval of Unit 8. Since thermal conductivity is the heat transfer capabilities of materials, the values depend on the chemical composition as well as density, porosity, texture, and water content (Blum, 1997; Clauser \& Huenges, 1995; Mielke et al., 2017). A distinct relationship with porosity has been described in several studies (e.g., Smith et al., 2013; Sumirat et al., 2006). However, Figure 8 b shows a scattered distribution in the correlation with low $R^{2}(0.41)$, which indicates that the heterogeneity of mineral composition is more critical than textural characteristics for the thermal conductivity in this altered volcanic sequence at Site U1513. 

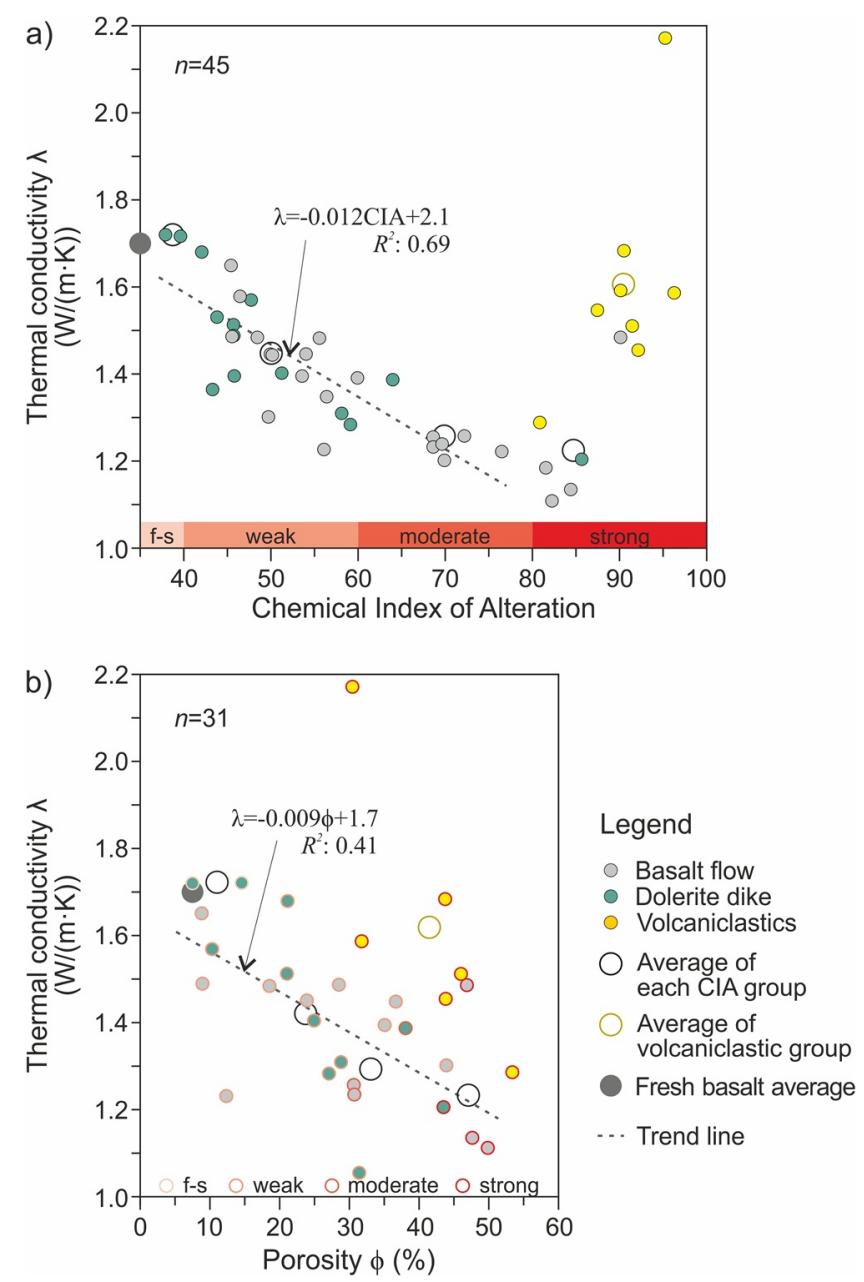

Figure 8. (a) Thermal conductivity versus Chemical Index of Alteration (CIA) and (b) Thermal conductivity versus Porosity, with the number $(n)$ of data points and the alteration intensity ranges. Linear trend lines with equation and $R^{2}$ are quantified for data from basalt flows and dikes. Average data point of each alteration range group (black circle), volcaniclastic samples (yellow circle), and fresh basalt from references (large gray dot) are presented for each plot. Offset between positions of thermal conductivity and CIA data is $\leq 30 \mathrm{~cm}$ within individual flows, but a few cases are $>30 \mathrm{~cm}$ based on lithologic description.

\subsection{Natural Gamma Ray}

The top of the volcanic sequence is characterized by a sharp drop in NGR from the overlying Unit V of volcaniclastic-rich sediments (Figure 9a). It is associated with sparseness of the radioactive elements in the mafic volcanic rocks. It corresponds to very low NGR values in the slightly altered dikes $(\leq 2.5 \mathrm{cps})$. NGR is usually emitted from the decay of mineral-hosted ${ }^{40} \mathrm{~K},{ }^{232} \mathrm{Th}$, and ${ }^{238} \mathrm{U}$ (De Vleeschouwer et al., 2017; Helm-Clark et al., 2004). K and Th contents are particularly associated with clay minerals, whereas $U$ content is often hosted in either clay minerals or organic matter. Thus, the NGR variations in the altered volcanic rocks may be correlated to clay mineral abundance, because of their ability to host large ionic sizes of radioactive elements in their lattice sites. However, the NGR value versus CIA has a weak positive correlation with scattered data points (Figure 9c). Since spikes in NGR are often observed at/near flow top breccia and volcaniclastic bed (Figure 9a), the higher NGR could be derived from secondary minerals bearing radioactive elements such as K-rich smectite and zeolite, precipitated at the intervals. In both holes, the highest NGR peaks are measured at Unit 8; $15.3 \mathrm{cps}$ in Hole D and $67.6 \mathrm{cps}$ in Hole E, which accompany higher Th and U content. We attribute this high NGR values to the presence of organic matter since phytoclasts were identified in the volcaniclastic samples (Figure 9c).

\subsection{Magnetic Susceptibility}

Magnetic susceptibility is a dimensionless measure of the intensity to which a material can be magnetized by an external magnetic field. The bulk magnetic susceptibility depends on the relative composition of ferromagnetic, anti-ferromagnetic and paramagnetic minerals in a sample, which varies by depositional environment, cooling rates, grain size, oxidation, and alteration (Delius et al., 2003; Fukuma, 1998; Helm-Clark et al., 2004). In the volcanic sequence at Site U1513, the magnetic susceptibility is highly variable and spreads up to $5729 \mathrm{IU}$ with a mean of $672 \mathrm{IU}$ at Hole D (Figure 9b). Some peaks are observed at flow boundaries, which could be derived from different magnetic mineralogy between lithologic units or lithologic characteristics of rapidly cooled fine-grained flow tops with stronger oxidation and alteration. But the magnetic susceptibility variations show no relations to CIA and alteration intensity (Figure 9b); similar value ranges are shown between relatively fresh dike in Unit 7 and strongly altered Unit 5. The intervals of highly variable magnetic susceptibility are associated with abundant iron oxide contents. The presence of magnetite corresponds to the three highest peaks at $\sim 710$, $\sim 730$, and $\sim 755$ m CSF-A (Riquier et al., 2021) but shows a weak positive correlation with $\mathrm{Fe}_{2} \mathrm{O}_{3}$ * content (Figure 9d). The volcaniclastic rocks with intense hematization exhibit relatively low susceptibility. This indicates that the variable magnetic susceptibility in this volcanic sequence is related mainly to iron oxide mineralogy (e.g., hematite, magnetite, and goethite) and oxidation degree.

\section{Discussion}

\subsection{Eruption Environment and Alteration Processes}

Based on the core observations, we infer at least five eruptive phases corresponding to the five flow packages (Figure 2a). The emplacement mechanism and eruption environment contributed significantly to lithologic characteristics, alteration intensity and type, and consequently to the final petrophysical properties. Similar flow types occur in Units 5, 7, and 9, where massive flows at the bottom fade into thin, lobate flows at the top. The presence of reddened tops, high vesicularity, and angular vesicles in the upper parts of these units 


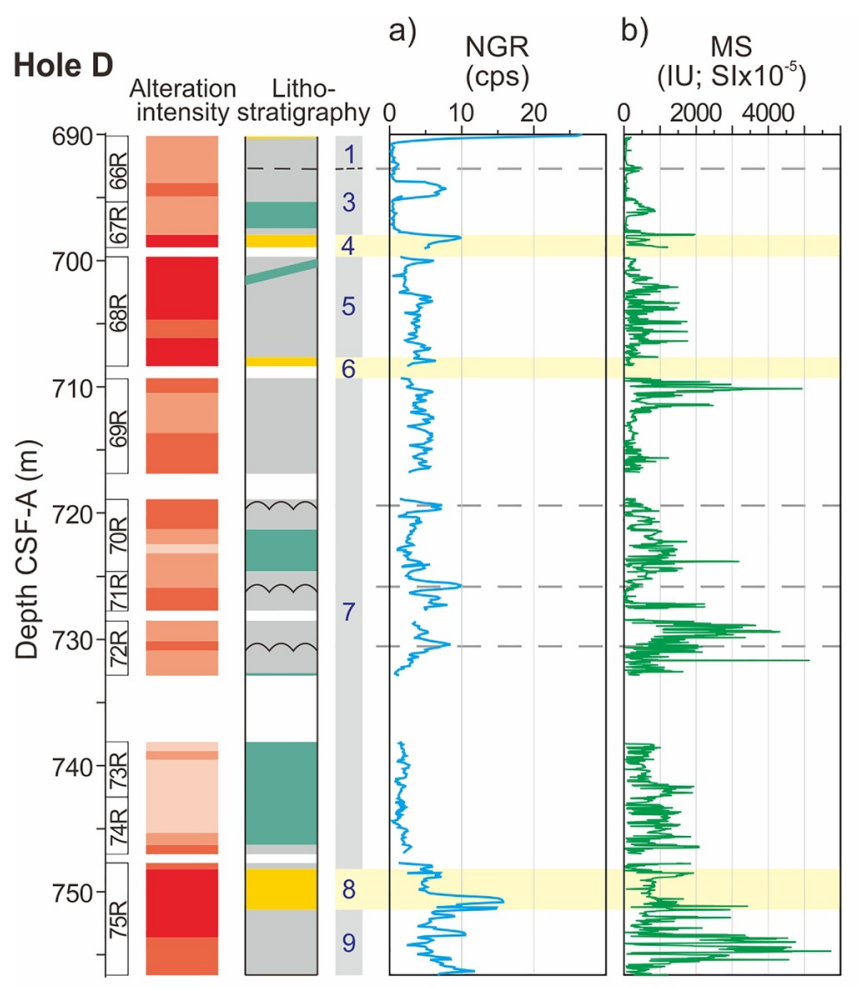

c)

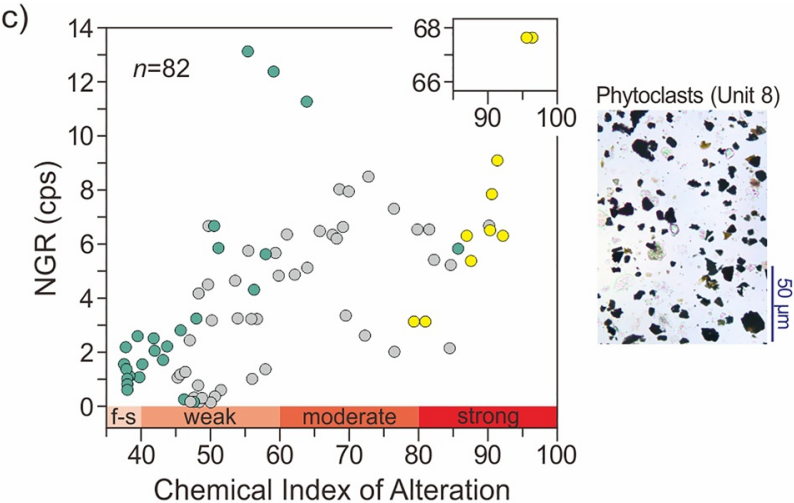

d)



Legend

- Basalt flow

- Dolerite dike

- Volcaniclastics

Alteration intensity

fresh-slight

weak

- moderate

o strong

Figure 9. (a) Natural Gamma Ray (NGR) and (b) magnetic susceptibility (MS) data of the volcanic sequence at Hole D. Lithostratigraphy and core number are presented with alteration intensity (from Figure 5a). cps: counts per second. IU: Instrument Unit (SI unit $\times 10^{-5}$; Searle, 2008). Correlation plots of (c) NGR versus Chemical Index of Alteration (CIA) and (d) MS versus $\mathrm{Fe}_{2} \mathrm{O}_{3}{ }^{*}$ content of Holes D and E, with the number $(n)$ of data points. Phytoclasts described at Unit 8 are shown (Sample U1513E-7R-1, 67-69 cm). Offset between positions of NGR and CIA data is $\leq 5 \mathrm{~cm}$. Offset between positions of MS value and Fe ${ }_{2}{ }_{3}{ }^{*}$ content is $\leq 1.25 \mathrm{~cm}$.

suggest subaerial emplacement of the flow sequence. On the other hand, the massive and non- to sparsely vesicular nature of Unit 1 and Unit 3 flows, combined with their greenish-gray color and absence of subaerial oxidization, suggest eruption in a submarine setting. This changing eruptive setting can be indicative of emplacement in a subsiding basin (Harry et al., 2020). The ongoing subsidence is indicated in the deposition of overlying volcaniclastic-rich sediments from shelf to upper bathyal depths (Lee et al., 2020). We infer that the syn- to post-rift tectonic movements from the Valanginian to Aptian contributed to structural deformations and hydrothermal activity in this volcanic sequence. The post-emplacement faulting and fracturing led to the development of microcracks and fractures forming secondary pore space. The hydrothermal veins are observed throughout the volcanic and volcaniclastic-rich sequences (Huber et al., 2019b). Some dike intrusions might be coeval with the hydrothermal activity as indicated by the higher temperature alteration at dike margins. The occurrence of hydrothermal activity toward the Aptian could have been driven by the latest magmatic fluxes at the end of breakup between Greater India and Australia-Antarctica and the proximity or high temperature of the Kerguelen and/or other mantle plume(s) (Harry et al., 2020; Lee et al., 2020; Olierook et al., 2017; White et al., 2021).

The emplacement of Units 9 to 5 was likely punctuated by subaerial weathering period and interlayering deposition of fragmented materials derived from nearby subaerial eruptions, as indicated by volcaniclastic units 4, 6, and 8. The gradational to erosional boundaries of Unit 5 and Unit 9 with the overlying volcaniclastic flows support the in situ mechanical and chemical weathering near surface. The processes transformed the basalt flows into highly porous layers in addition to abundant vesicles of the flow tops. Greater surface area, volume of pore fluids, and often greater permeability that allow fluids to access the rock mass all act as a function of increased pore sizes. This enhanced formation of secondary minerals such as clay, serpentine, 
zeolite, and calcite in the moderately to strongly altered intervals. The low temperature alteration processes represented by smectites and hematites are well observed in Unit 5, upper flows in Unit 7 and Unit 9, and volcaniclastic flows, which could have been caused by seawater-basalt interaction. The dominant alteration types are indicated as argillization (Na-Ca-rich smectite, illite, and kaolinite as a result of replacing feldspars at low temperature) and hematization (hematite replacement of Fe-oxide minerals, associated with potassium feldspar, sericite, chlorite, and epidote, by oxidizing/saline fluids) (e.g., Alt et al., 1996; Bain et al., 1980; Chesworth et al., 2004; García-Romero et al., 2005). The smectite-goethite \pm serpentine assemblage in the sections indicates the low temperature alteration of olivine (Chesworth et al., 2004). But the presence of higher temperature alteration minerals such as chlorite, calcite, and zeolite (Figure 4) suggests hydrothermal alteration overprint in these units.

During hydrothermal activity, the hydrothermal alteration was selective and more intense in the permeable intervals such as weathered basalt flows, fractured/brecciated boundaries, and volcaniclastic beds, which might play a role as pathways of circulating fluids (e.g., Caspari et al., 2020; Navelot et al., 2018). The intervals' alteration was enhanced toward stronger intensity by hydrothermal fluids in higher temperature and lower $\mathrm{pH}$ conditions. In Unit 9 to Unit 4, as a result, we indicate three major cycles of increasing alteration intensity, upward from less altered massive flows to strongly altered thin/lobate flows and volcaniclastic beds (Figure 5a). The abundant kaolinite minerals in strongly altered sections (Figures $4 \mathrm{~d}$ and $4 \mathrm{e}$ ) could be explained by alteration by hydrothermal fluid as well as by diagenetic weathering during the exposure under humid climatic conditions (Bain et al., 1980; Çelik et al., 1999). We interpret that the alteration of fresher sections including basalt flows of Unit 1 and Unit 3, flow interiors, and dikes was mostly induced by hydrothermal fluids during burial. It is supported by the presence of corrensite (chlorite/vermiculite) and vermiculite in the weakly altered sections (Figure $4 \mathrm{~b}$ ), which occurs in the early stages of hydrothermal alteration (Aspandiar \& Eggleton, 2002; Büchl \& Gier, 2003). The gradients for $\mathrm{Mg}, \mathrm{K}$, and $\mathrm{Na}$ (potentially as well $\mathrm{Li}$ ) in the pore waters derived from the overlying sedimentary sequence (Huber et al., 2019b) also indicate that the basaltic rocks and volcaniclastic layers are still showing signs of active alteration. The loss in Na from the pore waters is significant and supports the formation of Mg-rich chlorite and other clay minerals and possibly albitization in the underlying volcanic sequence. In parallel, the release of $\mathrm{Ca}$ and $\mathrm{Sr}$, and the occurrence of hydrothermal minerals such as sericite, carbonate, zeolite as well as calcite and hematite-chlorite veins, and occasional native copper dissemination (Riquier et al., 2021; Tejada et al., 2020) also support hydrothermal alteration (e.g., Schlegel \& Heinrich, 2015). Since the disruption of the crystal structure of vermiculite is necessary in its alteration to kaolinite, undifferentiated clays described in the moderately to strongly altered rocks (Figures 4c-4e) might be attributed to vermiculite or interstratified kaolinite-vermiculite stage. Goethite in pore spaces likely formed due to the Fe release during the alteration of vermiculite to kaolinite (Aspandiar \& Eggleton, 2002). We indicate two major hydrothermal alteration types of chloritization (chlorite-montmorillonite-zeolite \pm corrensite alteration of iron and magnesium bearing minerals such as pyroxene and olivine at higher temperature) and sericitization (kaolinite, $\mathrm{K}-\mathrm{Fe}-\mathrm{Mg}$ mica, sericite, and goethite alteration of feldspars and mafic minerals under high temperature and low pH condition) (e.g., Aspandiar \& Eggleton, 2002; Büchl \& Gier, 2003; Figueiredo e Silva et al., 2020; García-Romero et al., 2005; Mathieu, 2018; Schenato et al., 2003).

\subsection{Controls in Petrophysical Properties by Alteration}

The petrophysical properties of slightly altered dikes with sparse clays (CIA 35-40) are similar with average values of fresh basalts in reference literature $\left(\sim 2.7 \mathrm{~g} / \mathrm{cm}^{3}\right.$ in bulk density, $5 \%-10 \%$ or higher in porosity, $\sim 5,500 \mathrm{~m} / \mathrm{s}$ in $P$-wave velocity, and $\sim 1.7 \mathrm{~W} /(\mathrm{m} \cdot \mathrm{K})$ in thermal conductivity). Primary textural condition causes some variations, particularly in porosity and $P$-wave velocity (Figures $6 \mathrm{c}$ and $7 \mathrm{a}$ ). In the weak alteration range (CIA 40-60), the petrophysical properties are scattered with CIA, which overlap part of those in the fresh-slight and moderate alteration ranges. The spread reflects the increasing complexity in mineralogical composition and textural characteristics, which is the result of an interplay between primary lithologic characteristics and secondary processes attributed to hydrothermal alteration and post-emplacement fracturing. The lower density of smectite $\left(2.0-2.6 \mathrm{~g} / \mathrm{cm}^{3}\right)$ and vermiculite $\left(2.3-2.7 \mathrm{~g} / \mathrm{cm}^{3}\right)$, altered mostly from plagioclase $\left(\sim 2.7 \mathrm{~g} / \mathrm{cm}^{3}\right)$, affected a decrease in grain density. The large variation of porosity $(8.8 \%-32.1 \%)$ is interpreted to be caused by a complex framework of vesicles, microcracks, and fractures by primary and secondary processes. Since porosity affects the elastic moduli of rocks, the porosity values are closely associated 
with $P$-wave velocities spread between 2,025 and $5,378 \mathrm{~m} / \mathrm{s}$. The distribution, orientation and shape of pore space and pore-filling material could contribute to the velocity variation (Carlson, 2010; Durán et al., 2019; Marion \& Nur, 1991). The secondary mineral type also has an effect to wave velocity due to differences in elastic moduli and water affinity. According to Adam et al. (2013) and Wyering et al. (2014), volcanic rocks with chlorite and carbonate alteration have faster compressional wave propagation compared to altered rocks with smectite. However, the porosity change has no notable correlation with the thermal conductivity decrease (Figure $8 \mathrm{~b}$ ). This indicates that the decrease resulted from mineralogical changes by alteration processes, likely due to clay formation (e.g., smectite minerals $0.5-1.3 \mathrm{~W} /(\mathrm{m} \cdot \mathrm{K})$; Beziat et al., 1988). When the alteration intensity transitions to a moderate alteration range (CIA 60-80), the petrophysical property values become less scattered and converge toward the value ranges of the strong alteration range. The strongly altered rocks (CIA $80-100$ ) exhibit $\sim 2.0 \mathrm{~g} / \mathrm{cm}^{3}$ in bulk density, $40 \%-50 \%$ in porosity, $\sim 2,000 \mathrm{~m} / \mathrm{s}$ in $P$-wave velocity, and $\sim 1.2 \mathrm{~W} /(\mathrm{m} \cdot \mathrm{K})$ in thermal conductivity. Particularly, $P$-wave velocity of $\sim 2,000 \mathrm{~m} / \mathrm{s}$ is a significant indicator to discriminate the strongly altered basalt flows and volcaniclastic rocks in the sequence (Figure 5d). This is attributed to clastic-like framework stiffness and fabric characteristics induced by clay formation and microcracks as well as high porosity (Delayre et al., 2020). The thermal conductivity is generally near $1.2 \mathrm{~W} /(\mathrm{m} \cdot \mathrm{K})$ in clay-rich altered samples, but hematized samples show higher values (e.g., hematite $\sim 12.5 \mathrm{~W} /(\mathrm{m} \cdot \mathrm{K})$; Clauser \& Huenges, 1995).

Our results indicate that the petrophysical properties of volcanic sequence at Site U1513 are mainly controlled by the primary lithology formed during lava emplacement and weathering near surface, as well as the changes in bulk mineral composition by diagenetic and hydrothermal alteration processes. The major petrophysical control of the fresh-slightly to weakly altered rocks is exerted by the primary rock structure and texture formed during lava emplacement. Minor control is attributed to clay formation by hydrothermal fluids. In the moderately to strongly altered rocks, secondary minerals' physical properties play a major role, since primary feldspars and mafic minerals were pervasively replaced by clay minerals such as smectite and chlorite (Figures $4 \mathrm{c}$ and $4 \mathrm{~d}$ ). The iron oxide contents affect physical properties of strongly altered rocks. This indicates that, above a CIA value of 60 , secondary alteration minerals and associated textural change prevail over the primary igneous characteristics. Porous conditions ( $>30 \%$ in porosity) might be essential to induce stronger hydrothermal alteration in the basalt flows. Size, distribution, connectivity, and orientation of pores deformed by alteration processes could contribute to modifications of petrophysical properties (Griffiths et al., 2017; Heap et al., 2014).

The petrophysical variations recognized in continuous log-type data such as GRA, NGR, and magnetic susceptibility yield insights to understanding the volcanic stratigraphy. They are attributed to mineralogical and textural differences between lithologic units or at the boundaries. In the GRA data, lower bulk density indicates strongly altered basalt flows, lithologic or structural margins, and volcaniclastic beds, while higher bulk density is correlated with less altered flow interiors and dikes (Figures 5a and 5b). This allows us to observe the cyclic variations of petrophysical properties with increasing alteration intensity from flow core to top and bottom margins in a single basalt flow, which have been widely recognized in continental flood basalt sequences (e.g., Helm-Clark et al., 2004; Millett et al., 2016; Planke, 1994; Planke, Alvestad, \& Eldholm, 1999; Rossetti et al., 2019; Zakharova et al., 2012). In our study, the pattern is apparent in completely cored discrete flows without dike intrusion (e.g., Unit 1). This shows typical textural characteristics of inflated flood basalt flows, with an upper vesicular crust, a central massive core, and a thin basal vesicular crust (Self et al., 1997). The cyclic variation has been used as basis to analyze the volcanic stratigraphy in this study and previous studies. For example, in logging studies of the Columbia River flood basalt, high porosity $(20 \%-50 \%)$ in the altered brecciated flow tops contrasts with low porosity $(0 \%-10 \%)$ in relatively fresh massive flow interiors (Zakharova et al., 2012). In the northeastern Atlantic margins, the $P$-wave velocity increases from 2,000-3,000 m/s in the top to 5,000-6,000 m/s in the interior and decreases rapidly near the base (Planke, Alvestad, \& Eldholm, 1999). The petrophysical values from the logging data are similar to results from discrete samples of our study. We observed that NGR and magnetic susceptibility datasets have a potential application to volcanic stratigraphy. Sharp changes or peaks of the data are often correlated with lithologic boundaries and volcaniclastic beds (Figures 9a and 9b). NGR spikes correspond to precipitation of potassium-bearing secondary minerals such as K-rich smectite, zeolite, which are commonly infilling pore space by oxidizing and hydrothermal fluid circulation (e.g., Bartetzko et al., 2005; Fontana \& Tartarotti, 2013; Planke, 1994; Révillon et al., 2002). But the high NGR values in Unit 8 and the topmost flow of Unit 
9 (Figure 9a) cannot be explained by the secondary minerals alone. We suggest that the volcaniclastic flows might be mixed with neighboring or pre-existing potassium- and thorium-bearing sediments. This idea is potentially supported by a transcontinental fluvial system routing sediments from East Antarctica along the eastern margin of the Naturaliste Plateau at this time (Maritati et al., 2021). The sediments could partly infill the rough surface of the vesicular and brecciated top of underlying lava flows. This is likely associated with organic matter traces found in the volcaniclastic flow. Peaks in the magnetic susceptibility often correspond to lithologic boundaries, which are related to fine grains derived from rapidly cooled or brecciated flow tops or to different oxidation and alteration state. However, its application is limited due to its close association to iron oxide mineralogy and oxidation degree (Delius et al., 2003; Fukuma, 1998; Helm-Clark et al., 2004; Planke, Cerney, et al., 1999).

\subsection{Alteration Effects on Velocity-Porosity Relationships}

The strongly altered basalt flows show porosity of $43.5 \%-49.9 \%$ and the moderately altered basalt flows $30.7 \%-46.2 \%$ (Figure $5 \mathrm{c}$ ), which are exceptionally high values in altered volcanic rocks. Consequently, the high porosity led to decreases in bulk density to $\sim 2.0 \mathrm{~g} / \mathrm{cm}^{3}$ and $P$-wave velocity to $\sim 2,000 \mathrm{~m} / \mathrm{s}$. Similar high porosity values of $20 \%-50 \%$ were reported from the Columbia River flood basalt (Zakharova et al., 2012), but these data were restricted to brecciated flow tops. In our study, the high porosity values are from a basalt flow pile in Unit 5 and upper flows of Unit 7 and Unit 9. We interpret this as resulting from an interplay of the high vesicularity and autobrecciation during emplacement in subaerial setting and subsequent weathering and denudation near surface that cause the physical fragmentation and mineral dissolution by meteoric water (e.g., Navarre-Sitchler et al., 2015; Wyering et al., 2014). Alternatively, the pore sizes were enlarged during burial, due to mineral dissolution by hydrothermal fluids and further minor crack propagation during the reactions (e.g., Kanakiya et al., 2017). Some secondary pores were associated with post-emplacement fractures and faults by tectonic activity. But there are also processes that can cause pore space reduction during burial. For instance, pores can collapse and be deformed due to vertical stress and occluded by secondary mineral precipitation by fluid circulation (e.g., zeolite; Schenato et al., 2003). Such features were observed in the volcanic sequence at Site U1513 (Tejada et al., 2020), but the processes causing pore size enlargement or reduction during burial are associated with each other. We concluded that most of the high porosity of the studied rocks was formed near the surface. Another possibility affecting the porosity is that drilling damage and uncorrected clay effects may bias the values. However, we assume that clay swelling and associated microcracks during storage and measurement may not be significant since there is little porosity difference between Holes D and E, even though porosity of Hole E samples was measured after 2-year core storage (Lee \& Song, 2021). When we consider the clastic-like matrix and clay-rich composition in the high-porosity intervals, the moderately to strongly altered samples are petrophysically similar to clastic rocks. The porosity range is in accordance with $18 \%-49 \%$ of fine- and coarse-grained sediments in the burial depth, 690-770 m (Kim et al., 2018). This also corresponds to the porosity of the volcaniclastic rocks, suggesting that the low $P$-wave velocity near $2,000 \mathrm{~m} / \mathrm{s}$ is representative for the strongly altered rocks. Similarly, according to Planke, Cerney, et al. (1999), strongly altered basalts of clay proportion exceeding $60 \%$ show $P$-wave velocity near $2,000 \mathrm{~m} / \mathrm{s}$. A relation between porosity and $S$-wave velocity in altered basalt flows has been reported (e.g., Rossetti et al., 2019), but it is not apparent in our results. This likely results from various secondary minerals and textural changes, which is correlated with variable Poisson's ratio from 0.1 to 0.35 . Similar cases have been observed at other altered basalt terrains (e.g., Prasanna Lakshmi et al., 2014).

Theoretical predictions for the relation between seismic wave velocity and porosity in porous rocks have been introduced based on the effective medium theory with the elastic moduli of solid and fluid phases and their volume fractions (Bosch et al., 2014; Hashin \& Shtrikman, 1963; Marion \& Nur, 1991; Nur et al., 1998). The elastic properties of the solid phase depend on the mineral composition. At a given volume fraction of fluid (porosity) and mineral composition (solid skeleton), the seismic wave velocity varies with pore geometry, because the compressibility of pore space is dependent on its shape (Avseth et al., 2010). Thus, what we can do is only to specify a range of the effective property with lower and upper bounds. The lower and upper velocity bounds for a rock can be theoretically predicted with rock physics models for two extreme cases of pore compressibility; the Hashin-Shtrikman model (Hashin \& Shtrikman, 1963) and the Voigt-Reuss model (Reuss, 1929; Voigt, 1910). 


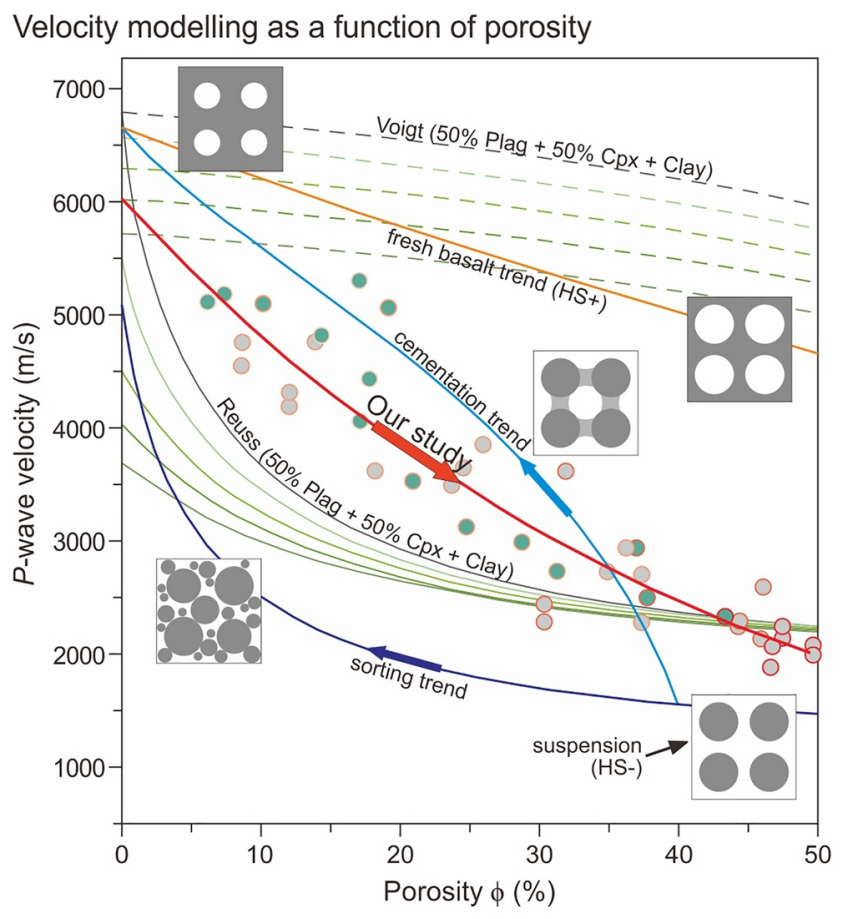

\begin{tabular}{|c|c|c|c|}
\hline \multicolumn{4}{|l|}{ Legend } \\
\hline $\begin{array}{l}\text { Hashin-Shtrikm } \\
\text { fresh bas } \\
\text { cementat } \\
\text { sorting tre }\end{array}$ & $\begin{array}{l}\text { del } \\
\text { d }\end{array}$ & $\begin{array}{l}\text { Voigt-Reuss model } \\
50 \% \text { Plag }+50 \% \text { Cpx }+ \text { Clay }\end{array}$ & $\begin{array}{l}0 \%--- \\
10 \%--- \\
20 \%--- \\
30 \%-- \\
40 \%--\end{array}$ \\
\hline $\begin{array}{l}\text { Lithology } \\
\text { Basalt flow } \\
\text { Dolerite dike }\end{array}$ & $\begin{array}{l}\text { Alterati } \\
\text { fresh- }\end{array}$ & $\begin{array}{l}\text { n intensity } \\
\text { light } \circ \text { weak } \circ \text { moderate }\end{array}$ & o strong \\
\hline
\end{tabular}

Figure 10. Velocity modeling as a function of porosity. The porosityvelocity trend of basalts established in our study is shown with data points (thick red line; Figure 7b). The Hashin-Shtrikman model (Hashin $\&$ Shtrikman, 1963) for the range of seismic velocity as a function of porosity was calculated using data of bulk and shear moduli in previous studies (e.g., Christensen, 1972). The upper bound (HS+) for a porous medium with the stiffest pore structure (a model of fresh vesicular basalt) and the lower bound (HS-) for the softest pore structure (suitable for sediments suspended in water) are provided. If the porosity of sediments becomes lower than a critical value (near $40 \%$ ), it will be reduced further by cementation or sorting as shown in small boxes (Nur et al., 1998). The Voigt-Reuss model is from Rossetti et al. (2019) that estimates the relative effects of lithologic variation in velocity versus porosity. The calculated elastic bounds represent the stiffest and softest possible mixture of components at any one porosity. A simplified basalt composition of $50 \%$ plagioclase and $50 \%$ pyroxene is as a starting baseline. The effects of alteration were modeled by the incremental addition of clay (smectite) up to $40 \%$.
For the Hashin-Shtrikman model in Figure 10, the bulk and shear moduli for basalt modeling are the same as those used in previous studies (e.g., Christensen, 1972). The upper and lower bounds represent the stiffest pore shape (spherical or equant pores) and the softest pore shape (suspension or connected flat microcracks), respectively (Mavko et al., 2020). Fresh vesicular basalt without microcracks can be an example of the upper bound ( $\mathrm{HS}+$ ), while sediments suspended in water (porosity $>40 \%$ ) are applied to the lower bound (HS-). The range in between is interpreted as a mixture of two extreme cases with their different ratios. The porosity-velocity trend of our study (Figure $7 \mathrm{~b}$ ) is much lower than the slope obtained for a fresh basalt constituent with spherical pores (HS+). The difference becomes larger with increasing porosity (Figure 10). This distinct weakening (softening) of rock framework with porosity increase is interpreted as resulting from alteration processes associated with clay formation and microcracks. Our porosity-velocity trend shows a different behavior from those found in diagenetic process of sedimentary rocks like cementation or sorting.

We compared our result to the Voigt-Reuss model calculated by Rossetti et al. (2019) to estimate the relative effects of lithologic variations for different circumstances (Figure 10). The Voigt-Reuss model states also the elastic bounds representing the stiffest and softest possible mixture of components at any one porosity. The Voigt (arithmetic) and Ruess (harmonic) averages of seismic velocity were derived from parallel (isostrain) and series (isostress) distribution of components, respectively (e.g., Wang \& Pan, 2008). However, the Voigt-Reuss model used in this study demonstrates that the velocity variation occurs for clay formation rather than pore structure changes. A simplified basalt composition of $50 \%$ plagioclase and 50\% pyroxene was applied as a starting baseline. The effect of alteration was modeled by the incremental addition of smectite up to $40 \%$. Our velocity-porosity data generally fall between these bounds. But, some data, mostly from moderately to strongly altered basalts, extend to below the lower bound (Figure 10), which indicate that the pore-rock framework was softer than the modeled minimum. The trend derived from our results passes near the lower limit of sediments suspended in water (HS-) as well as moves below the Reuss lower bounds, which supports the petrophysical similarity between strongly altered basalts and clastic sediments.

\subsection{Application to Drilling and Geophysical Prospecting Involving Volcanic Rocks}

We compared our results to correlations of shipboard petrophysical property data and CIA acquired from volcanic rocks cored at other IODP and Ocean Drilling Program (ODP) drilling sites (Figure 11). There are limited data available in the moderately to strongly altered intervals, which may be because these rocks were potentially avoided in the measurement and sampling during most expeditions, combined with it being difficult to recover the altered intervals using rotary drilling techniques (Planke, Cerney, et al., 1999). In particular, the thermal conductivity data cannot be reliably compared due to the lack of available data (Figure 11e), likely due to difficulty of obtaining thermal conductivity measurements from often fractured/fragmented cores. The correlations of grain density, bulk density, porosity, and $P$-wave velocity with CIA at other sites follow similar trends as recorded from the rocks sampled at Site U1513 (Figures 11a-11d). This suggests that there are no inherent differences due to emplacement at different tectonic settings. However, the large dispersal represents the significance of 


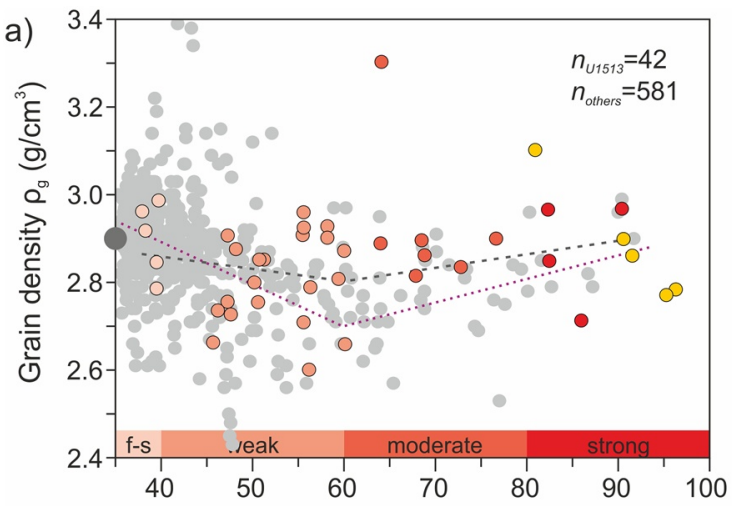

Legend
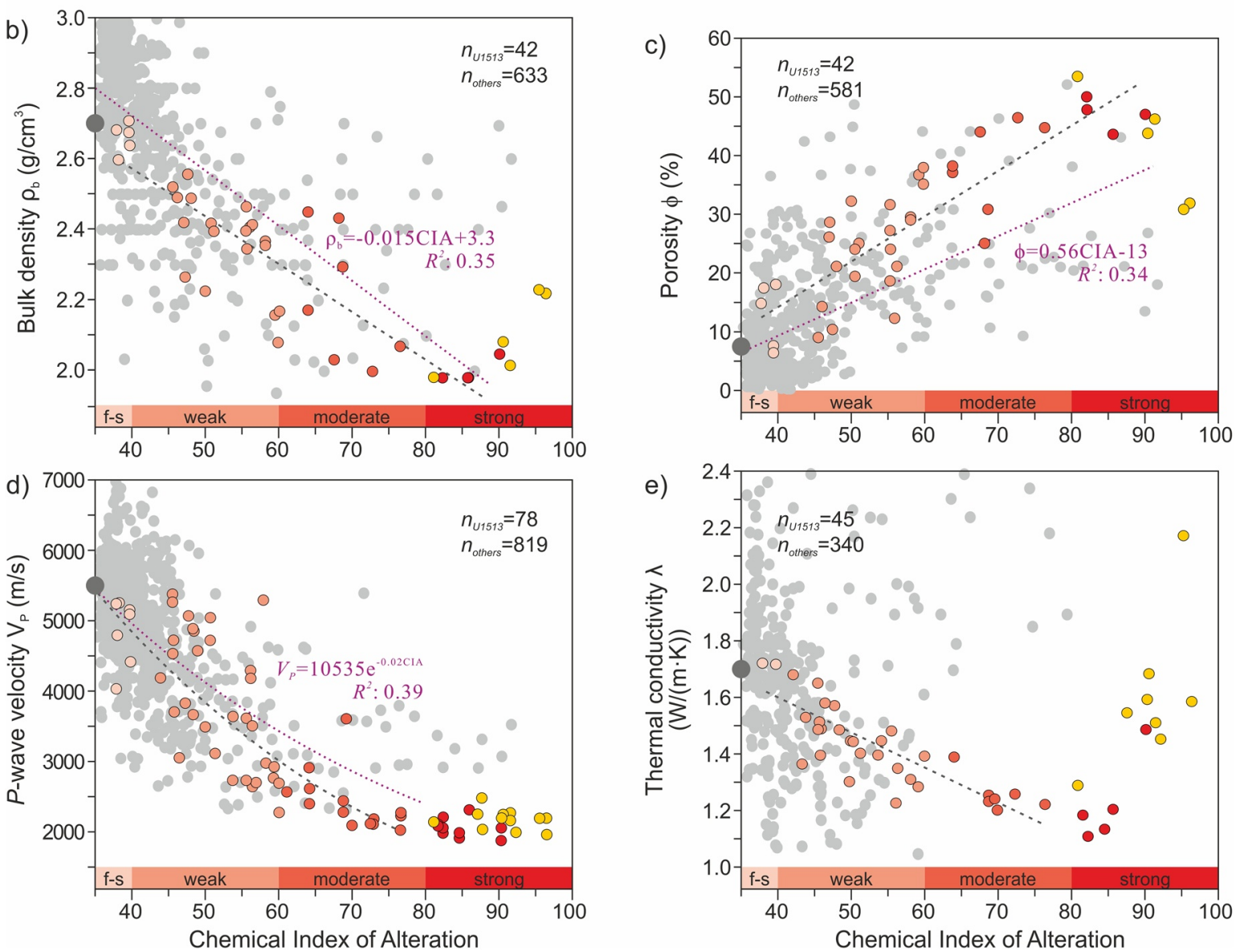

Figure 11. Plots of petrophysical property versus Chemical Index of Alteration (CIA) of volcanic rocks; (a) Grain density, (b) Bulk density, (c) Porosity, (d) $P$-wave velocity, (e) Thermal conductivity. Results of IODP Site U1513 are from Figures 6-8. The data from volcanic rocks cored at other IODP and ODP sites are from shipboard petrophysical measurement, X-ray fluorescence (XRF) and Inductively Coupled Plasma-Atomic Emission Spectrometers (ICP-AES) analyses (http://web.iodp.tamu.edu/OVERVIEW/). Trend lines with equation and $R^{2}$ are quantified. Offset between data positions of petrophysical property value and CIA content is $\leq 30 \mathrm{~cm}$. The IODP and ODP sites are U1527-U1531, U1502, U1438-U1442, U1433-U1434, U1431, U1382-U1383, U1372-U1374, U1362, U1256, 1203-1206, 1201, 1185-1189, 1136-1140, 988-990, 917-918, 871-872, 856, 829-841, 801, 797, 794-795, 791, 765-770, 756-758, 747-750, 715, 713, 648, 504.

mineralogical and geochemical variations introduced by primary lithology, alteration mineralogy, hydrothermal fluid, and environmental conditions of stress, temperature, and $\mathrm{pH}$. It is evident that the thermal conductivity data are sensitive to mineralogical composition and fluid chemistry. 
Schematic synthesis of petrophysical variations with alteration intensity: Basalts at IODP Site U1513
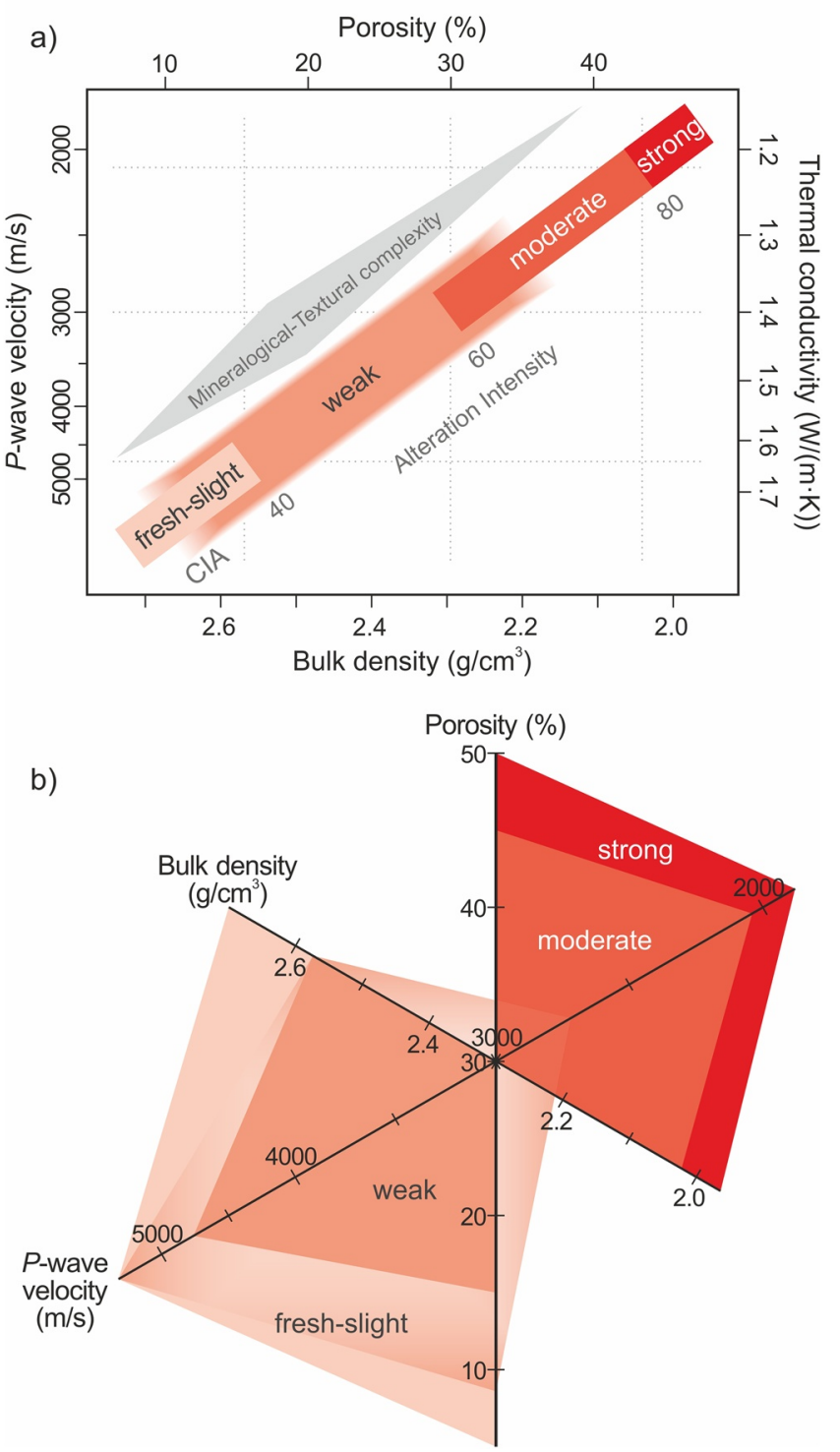

Figure 12. Schematic synthesis models in correlations of petrophysical variations and alteration intensity ranges of basalts at Site U1513. Petrophysical variations are of bulk density, porosity, $P$-wave velocity, and thermal conductivity in the synthesis (a). Thermal conductivity is not included in the synthesis (b). The petrophysical characteristics in the weak alteration range overlap part of those in the fresh-slight and moderate alteration ranges. Relationships between datasets are adjusted using quantified trend lines in Figures 6-8.
Petrophysical datasets correlate well with independent indicators of alteration intensity of basalt flows and associated volcaniclastic rocks at Site U1513, providing a metric to rapidly characterize volcanic sequences. Our results demonstrate that variations in petrophysical datasets have applicability to complement traditional lithologic and mineralogical investigations when assessing the alteration of volcanic rocks. Increasing alteration intensity in the basalt flows and dikes at Site U1513 corresponds to decreases in bulk density, $P$-wave velocity, thermal conductivity, and an increase in porosity. A synthesis of the correlations is presented in Figure 12a. However, the thermal conductivity shows a distinct variation depending on hematization degree in strongly altered rocks. It has no clear relationship with porosity that is a major controlling parameter showing excellent correspondence with bulk density and $P$-wave velocity $\left(R^{2} \geq 0.85\right)$. Thus, we suggest a synthesis of porosity, bulk density, and $P$-wave velocity in Figure $12 \mathrm{~b}$, which corresponds mainly to textural characteristics and clay formation. These correlation plots can be used as a tool to evaluate alteration-derived petrophysical variations. In both models, the petrophysical properties in the weak alteration range overlap part of those in the fresh-slight and moderate alteration ranges.

Scientific drilling projects such as IODP, International Continental Scientific Drilling Program (ICDP) or commercial projects routinely conduct petrophysical measurements. The evaluation of volcanic rocks from wireline logging data is typically the common route for appraising boreholes due to cost and technical difficulty to recover the altered volcanic intervals. It is difficult to perform continuous lithologic description and petrophysical measurement on the fragile and often fragmented core sections. Detailed volcanic stratigraphy has been derived from geophysical logs without cores, relying on cuttings and wireline. This is also key for geothermal exploration because commercial wells are rarely cored and alteration mineralogy is derived from cuttings in coordination with wireline log data (Jerram et al., 2019; Millett et al., 2016; Planke, Cerney, et al., 1999). Thus, our petrophysical study using core data is integral to better inform these correlations and calibrate wireline log-based determinations for settings where cores are not available. The petrophysical variations, described from the volcanic sequence at Site U1513, can provide a guideline for preliminary evaluation of alteration intensity through continuous logging data and subsequent correlation with alteration mineralogy from cuttings. During the logging while drilling (LWD), the alteration analysis can be supplemented by geochemical logging data such as the elemental capture spectroscopy and the aluminum activation log. This provides us with a tool to establish logging and sampling strategies. It is applicable to guide the future collection of fresh basalt samples for geochemical analyses (e.g., ${ }^{40} \mathrm{Ar}-{ }^{39} \mathrm{Ar}$ dating) or altered rock samples for alteration studies and/or economic mineral exploration campaigns. The mechanical changes of the altered rocks can be used to estimate drilling rate, recovery, and borehole condition (e.g., Fontana \& Tartarotti, 2013; Millett et al., 2016; Tartarotti et al., 2009; Tominaga et al., 2009) and to select the most appropriate petrophysics equipment to use for altered volcanic sequences. The investigation of porous and weakened clay-rich condition, associated with instability of underground volcanic fields (Ball et al., 2013; Delayre et al., 2020; Houston \& Smith, 1997), would be useful for rock mechanics in natural hazard assessment and geological engineering.

Onshore and offshore drilling projects commonly precede geophysical prospecting to estimate the overview of subsurface lithologic type and the structure for drilling site assessment and data acquisition strategies. 
Velocity-based prospecting (e.g., seismic reflection data) is a powerful tool to evaluate the aerial distribution of subsurface volcanic layers. In sedimentary basins, basement or syn-rift sequence is often composed of volcanic rocks, highlighting their importance in describing basin geometry. For example, in the Atlantic and Indian ocean margins, volcanic rocks are intrinsically associated with prolific hydrocarbon-bearing sedimentary basins (Direen et al., 2008; Millett et al., 2016; Planke, Alvestad, \& Eldholm, 1999). Seismic image quality and reflector characteristics vary significantly in volcanic terrains. Seismic facies are interpreted on the basis of the nature and geologic history of volcanic rocks and their emplacement environment. Seismic volcanostratigraphy provides important information for drilling through volcanic sequences when targeting sub-volcanic reservoirs or sedimentary interbeds trapped within the volcanic sequence. $P$-wave velocity data, as a useful tool to estimate porous condition (Figure 7), can serve as supplemental information to investigate volcanic facies and alteration intensity of subsurface rocks and to improve seismic imaging and processing (e.g., Jerram et al., 2019; Planke, Alvestad, \& Eldholm, 1999). Understanding the interplay between primary and secondary processes on the final petrophysical characteristics of the volcanic rocks is key to evaluate reservoir properties (Rossetti et al., 2019). If a hydrocarbon-bearing basin evolved with multiple volcanic eruptions, the volcanic layers could be a component of its petroleum system. Occasionally, hydrocarbons saturate altered and porous volcanic rocks, which become productive reservoirs. In the Junggar Basin, for instance, the Carboniferous volcanic reservoirs show 2\%-18\% in porosity with $20 \%-60 \%$ oil saturation (Wang et al., 2018). In the Songliao Basin, the Upper Jurassic volcanic reservoir has up to $16 \%$ porosity and up to $80 \%$ gas saturation (Jiang et al., 2017). Furthermore, environmental conditions such as temperature, inferred from the alteration type and intensity and syn- to post-emplacement history, may supplement estimation of hydrocarbon maturation and migration as well as reconstructing geothermal evolution of sedimentary basins. Understanding the behavior of physical properties with alteration will help us to establish the exploration strategy for calibrating production and injection models of the igneous-hosted reservoirs (e.g., Kristinsdóttir et al., 2010). The models are also associated with pore connectivity (further permeability) and fluid saturation, likely enhanced by fracturing and alteration (Delayre et al., 2020; Nara et al., 2011). The reservoir potential of volcanic rocks can also be applied to evaluate target sites of anthropogenic $\mathrm{CO}_{2}$ storage based on high mineral trapping capacity, unique structures, and enormous volumes (Gislason \& Oelkers, 2014; Xiong et al., 2018; Zakharova et al., 2012). Unlike sedimentary reservoirs where $\mathrm{CO}_{2}$ is primarily contained by a caprock or by dissolution in formation water, basalts have a key advantage for mineral trapping and carbonation in stable solid phase. In particular, continental flood basalts possess large storage capacity for $\mathrm{CO}_{2}$ injection (McGrail et al., 2006). Alteration conditions of basalts need to be studied thoroughly to evaluate storage capacity and to avoid fluid migration and structural instability. The correlation of volcanic stratigraphy with alteration intensity can supplement the reconstruction of the reservoir structure, where relatively fresh dike and flow interior may play a role as a caprock.

\section{Conclusions}

We investigated the relationship between petrophysical variation and alteration intensity by correlating petrophysical properties with CIA data from a volcanic sequence of the Naturaliste Plateau, offshore southwest Australia (IODP Site U1513). The sequence consists of basalt flows, volcaniclastic beds, and dolerite dikes. The primary lithologies and volcanic stratigraphy affected alteration intensity and type. The basalt flows were weakly to strongly altered by exposure to subaerial and shallow water weathering and hydrothermal activity. Formation of clay and other secondary minerals is attributed to interactions between basalt flows and meteoric, sea water, and hydrothermal fluids. Major alteration processes replaced plagioclase phenocrysts, mafic minerals, and groundmass by secondary minerals and formed vesicle and vein fillings. Dikes were relatively fresh or less altered, while volcaniclastic beds show strong alteration with hematization. The mechanical and mineralogical changes by alteration induced petrophysical property changes through the sequence. Key indicators of alteration and clay formation from petrophysical parameters in strongly altered basalts include increased porosity up to $50 \%$ and associated decreases in bulk density to $\sim 2 \mathrm{~g} / \mathrm{cm}^{3}, P$-wave velocity to $\sim 2,000 \mathrm{~m} / \mathrm{s}$, and thermal conductivity to $\sim 1.2 \mathrm{~W} /(\mathrm{m} \cdot \mathrm{K})$, compared to the values obtained from the least altered samples. The large petrophysical spread in weak alteration range are attributed to the heterogeneous distribution of various primary igneous and secondary characteristics. Stronger alteration is observed at/near weathered intervals and flow boundaries with vesicular and fragmental textures. The strongly altered basalt flows are petrophysically similar to clastic sediments, except in the 
high thermal conductivity intervals caused by intense hematization. In the examined volcanic sequence, NGR and magnetic susceptibility provided limited information on changes in lithology and the contacts between different volcanic flows. These results, arranged in synthesis plots that link multiple petrophysical variations to alteration intensity, can be applied as petrophysical guidelines for preliminary and quantitative alteration investigation. In geological and geophysical exploration projects, the correlation trends can contribute to the establishment of strategies for data acquisition, interpretation, sampling, and geochemical analyses and to calibrate wireline log-based determinations for volcanic stratigraphy and alteration intensity for settings where cores are not available. However, differences in primary lithology, alteration types, and fluid chemistry introduce limitations and uncertainties, which need to be considered in applications to other sites and geologic settings.

\section{Data Availability Statement}

This research used core samples provided by the International Ocean Discovery Program (IODP). Petrophysical, XRD and XRF data presented in this manuscript can be accessed via the data repository of IODP (https://web.iodp.tamu.edu/OVERVIEW/) and PANGAEA website (https://www.pangaea.de/) or found in IODP data reports (Lee \& Song, 2021; Riquier et al., 2021).

\section{Acknowledgments}

We thank shipboard scientists and the technical staff of IODP Expedition 369 and crew members of the JOIDES Resolution for their critical contributions. We acknowledge financial support by K-IODP by the Ministry of Oceans and Fisheries to E. Y. Lee, I. Song, S. S. Chun, Brain Pool program by the Ministry of Science and ICT through the NRF of Korea (2017H1D3A1A01054745) to E. Y. Lee, S. S. Chun, and J-DESC to M. L. G. Tejada. ANZIC provided financial support for analytical costs as well as for L. T. White's involvement in Expedition 369, supported by the Australian Government through the ARC LIEF Grant (LE160100067). ECORD and IODP-France supported L. Riquier and M. Martinez. Special thanks to Geoscience Australia for seismic profile data, D. Seoung for geochemical analysis, E. Wolfgring, M. Wagreich for thin section analysis, D. De Vleeschouwer for NGR analysis, Y. Kim for palynomorph analysis, S.W. Lee for ODP data analysis, V. Koukal for XRD analysis, C. Lehners, E. Gruendken for XRF analysis, and Y. Kubo, S. Nigi, R. Yamaoka of the KCC for facilitating our visit and core descriptions (Request No. 071241IODP). This manuscript was improved significantly by the thorough reviews of John Millett, Shreya Kanakiya, and Léa Lévy and the editorial handling of Stephen Parman and Ludmila Adam.

\section{References}

Adam, L., vanWijk, K., Otheim, T., \& Batzle, M. (2013). Changes in elastic wave velocity and rock microstructure due to basalt-CO2-water reactions. Journal of Geophysical Research: Solid Earth, 118, 4039-4047. https://doi.org/10.1002/jgrb.50302

Alt, J. C., Honnorez, J., Laverne, C., \& Emmermann, R. (1986). Hydrothermal alteration of a 1 km section through the upper oceanic crust, Deep Sea Drilling Project Hole 504B: Mineralogy, chemistry and evolution of seawater-basalt interactions. Journal of Geophysical Research, 91, 10309-10335. https://doi.org/10.1029/JB091iB10p10309

Alt, J. C., Laverne, C., Coggon, R. M., Teagle, D. A. H., Banerjee, N. R., Morgan, S., et al. (2010). Subsurface structure of a submarine hydrothermal system in ocean crust formed at the East Pacific Rise, ODP/IODP Site 1256. Geochemistry, Geophysics, Geosystems, 11, 10. https://doi.org/10.1029/2010GC003144

Alt, J. C., Laverne, C., Vanko, D. A., Tartarotti, P., Teagle, D. A. H., Bach, W., et al. (1996). Hydrothermal alteration of a section of upper oceanic crust in the eastern equatorial Pacific: A synthesis of results from Site 504 (DSDP Legs 69, 70, and 83, and ODP Legs 111, 137, 140, and 148). In J. C. Alt, H. Kinoshita, L. B. Stokking, \& P. J. Michael (Eds.), Proceedings of Ocean Drilling Program, scientific results (Vol. 148, pp. 417-434). ODP. https://doi.org/10.2973/odp.proc.sr.148.159.1996

Aspandiar, M. F., \& Eggleton, R. A. (2002). Weathering of chlorite: I. Reactions and products in microsystems controlled by the primary mineral. Clays and Clay Minerals, 50, 685-698. https://doi.org/10.1346/000986002762090227

Avseth, P., Mukerji, T., \& Mavko, G. (2010). Quantitative seismic interpretation: Applying rock physics tools to reduce interpretation risk. Cambridge University Press. https://doi.org/10.1017/CBO9780511600074

Babechuk, M. G., Widdowson, M., \& Kamber, B. S. (2014). Quantifying chemical weathering intensity and trace element release from two contrasting basalt profiles, Deccan Traps, India. Chemical Geology, 363, 56-75. https://doi.org/10.1016/j.chemgeo.2013.10.027

Bain, D. C., Ritchie, P. F. S., Clark, D. R., \& Duthie, D. M. L. (1980). Geochemistry and mineralogy of weathered basalt from Morvern, Scotland. Mineralogical Magazine, 43, 865-872. https://doi.org/10.1180/minmag.1980.043.331.07

Ball, J. L., Calder, E. S., Hubbard, B. E., \& Bernstein, M. L. (2013). An assessment of hydrothermal alteration in the Santiaguito lava dome complex, Guatemala: Implications for dome collapse hazards. Bulletin of Volcanology, 75, 676. https://doi.org/10.1007/s00445-012-0676-z

Bartetzko, A., Delius, H., \& Pechnig, R. (2005). Effect of compositional and structural variations on log responses of igneous and metamorphic rocks. I: Mafic rocks. In P. K. Harvey, T. S. Brewer, P. A. Pezard, \& V. A. Petrov (Eds.), Petrophysical properties of crystalline rocks (pp. 255-278). The Geological Society of London. https://doi.org/10.1144/GSL.SP.2005.240.01.19

Beziat, A., Dardaine, M., \& Gabis, C. (1988). Effect of compaction pressure and water content on the thermal conductivity of some natural clays. Clays and Clay Minerals, 36(5), 462-466. https://doi.org/10.1346/CCMN.1988.0360512

Bjørlykke, K. (2014). Relationships between depositional environments, burial history and rock properties. Some principal aspects of diagenetic process in sedimentary basins. Sedimentary Geology, 301, 1-14. https://doi.org/10.1016/j.sedgeo.2013.12.002

Blum, P. (1997). Physical properties handbook: A guide to the shipboard measurement of physical properties of deep-sea cores. Ocean Drilling Program, Technical Note, 26. https://doi.org/10.2973/odp.tn.26.1997

Borissova, I. (2002). Geological framework of the Naturaliste Plateau.Geoscience Australia.

Bosch, M., Mukerji, T., \& Gonzalez, E. F. (2014). Seismic, rock physics, spatial models, and their integration in reservoir geophysics. In V. Grechka, \& K. Wapenaar (Eds.), Encyclopedia of exploration geophysics (pp. M1-1-M1-56). Geophysical References Series. Society of Exploration Geophysicists. https://doi.org/10.1190/1.9781560803027.entry7

Broglia, C., \& Moos, D. (1988). In-Situ structure and properties of 110-Ma crust from geophysical logs in DSDP Hole 418. In M. H. Salisbury, \& J. H. Scott (Eds.), Proceedings of the Ocean Drilling Program, scientific results (Vol. 102, pp. 29-47). ODP. https://doi.org/10.2973/ODP.PROC.SR.102.113.1988

Büchl, A., \& Gier, S. (2003). Petrogenesis and alteration of tuffs associated with continental flood basalts from Putorana, northern Siberia. Geological Magazine, 140, 649-659. https://doi.org/10.1017/S0016756803008392

Carlson, R. L. (2001). The effects of temperature, pressure, and alteration on seismic properties of diabase dike rocks from DSDP/ODP Hole 504B. Geophysical Research Letters, 28, 3979-3982. https://doi.org/10.1029/2001GL013426

Carlson, R. L. (2010). How crack porosity and shape control seismic velocities in the upper oceanic crust: Modeling downhole logs from Holes 504B and 1256D. Geochemistry, Geophysics, Geosystems, 11, Q04007. https://doi.org/10.1029/2009GC002955 
Carlson, R. L. (2014). The effects of alteration and porosity on seismic velocities in oceanic basalts and diabases. Geochemistry, Geophysics, Geosystems, 15, 4589-4598. https://doi.org/10.1002/2014GC005537

Caspari, E., Greenwood, A., Baron, L., Egli, D., Toschini, E., Hu, K., \& Holliger, K. (2020). Characteristics of a fracture network surrounding a hydrothermally altered shear zone from geophysical borehole logs. Solid Earth, 11, 829-854. https://doi.org/10.5194/se-11-829-2020

Çelik, M., Karakaya, N., \& Temel, A. (1999). Occurrences of clay minerals in hydrothermally altered volcanic rocks, Eastern Pontides, Turkey. Clays and Clay Minerals, 47, 708-717. https://doi.org/10.1346/CCMN.1999.0470604

Chesworth, W., Dejou, J., Larroque, P., \& Rodeja, E. G. (2004). Alteration of olivine in a basalt from central France. Catena, 56, 21-30. https://doi.org/10.1016/j.catena.2003.10.018

Christensen, N. I. (1972). Compressional and shear wave velocities at pressures to 10 kilobars for basalts from the East Pacific Rise. Geophysical Journal International, 28, 425-429. https://doi.org/10.1111/j.1365-246X.1972.tb06140.x

Christeson, G. L., Morgan, S., Kodaira, S., Yamashita, M., Almeev, R. R., Michibayashi, K., et al. (2016). Physical properties and seismic structure of Izu-Bonin-Mariana fore-arc crust: Results from IODP Expedition 352 and comparison with oceanic crust. Geochemistry, Geophysics, Geosystems, 17, 4973-4991. https://doi.org/10.1002/2016GC006638

Clauser, C., \& Huenges, E. (1995). Thermal conductivity of rocks and minerals. In T. J. Ahrens (Ed.), Rock physics \& phase relations: A handbook of physical constants (Vol. 3, pp. 105-126). AGU Reference Shelf. https://doi.org/10.1029/RF003p0105

De Vleeschouwer, D., Dunlea, A. G., Auer, G., Anderson, C. H., Brumsack, H., de Loach, A., et al. (2017). Quantifying K, U, and Th contents of marine sediments using shipboard natural gamma radiation spectra measured on DV JOIDES resolution. Geochemistry, Geophysics, Geosystems, 18, 1053-1064. https://doi.org/10.1002/2016GC006715

Delayre, C., Mas, P. P., Sardini, P., Cosenza, P., \& Thomas, A. (2020). Quantitative evolution of the petrophysical properties of andesites affected by argillic alteration in the hydrothermal system of Petite Anse-Diamant, Martinique. Journal of Volcanology and Geothermal Research, 401, 106927. https://doi.org/10.1016/j.jvolgeores.2020.106927

Delius, H., Brewer, T. S., \& Harvey, P. K. (2003). Evidence for textural and alteration changes in basaltic lava flows using variations in rock magnetic properties (ODP Leg 183). Tectonophysics, 371, 111-140. https://doi.org/10.1016/S0040-1951(03)00202-6

Direen, N. G., Cohen, B. E., Maas, R., Frey, F. A., Whittaker, J. M., Coffin, M. F., et al. (2017). Naturaliste Plateau: Constraints on the timing and evolution of the Kerguelen Large Igneous Province and its role in Gondwana breakup. Australian Journal of Earth Sciences, 64, 1-19. https://doi.org/10.1080/08120099.2017.1367326

Direen, N. G., Stagg, H. M. J., Symonds, P. A., \& Colwell, J. B. (2008). Architecture of volcanic rifted margins: New insights from the Exmouth-Gascoyne margin, Western Australia. Australian Journal of Earth Sciences, 55, 341-363. https://doi. org/10.1080/08120090701769472

Durán, E. L., Adam, L., Wallis, I. C., \& Barnhoorn, A. (2019). Mineral alteration and fracture influence on the elastic properties of volcaniclastic rocks. Journal of Geophysical Research: Solid Earth, 124(5), 4576-4600. https://doi.org/10.1029/2018JB016617

Fedo, C. M., Nesbitt, H. W., \& Young, G. M. (1995). Unrevelling the effects of potassium metasomatism in sedimentary rocks and paleosols, with implications for paleo-weathering conditions and provenance. Geology, 23, 921-924. https://doi. org/10.1130/0091-7613(1995)023<0921:uteopm>2.3.co;2

Figueiredo e Silva, R. C., Lobato, L. M., Zucchetti, M., Hagemann, S., \& Vennemann, T. (2020). Geotectonic signature and hydrothermal alteration of metabasalts under-and overlying the giant Serra Norte iron deposits, Carajás mineral Province. Ore Geology Reviews, 120, 103407. https://doi.org/10.1016/j.oregeorev.2020.103407

Fontana, E., \& Tartarotti, P. (2013). Structural and petrophysical characterization of the upper basement crustal section at ODP/IODP Site 1256 (East Pacific Ocean). Geochemistry, Geophysics, Geosystems, 14, 2399-2431. https://doi.org/10.1002/ggge.20161

Fukuma, K. (1998). Origin and applications of whole-core magnetic susceptibility of sediments and volcanic rocks from Leg152. In A. D. Saunders, H. C. Larsen, \& S. W. Wise (Eds.), Proceedings of the Ocean Drilling Program, scientific results (Vol. 152, pp. 271-280). ODP. https://doi.org/10.2973/odp.proc.sr.152.225.1998

García-Romero, E., Vegas, J., Baldonedo, J. L., \& Marfil, R. (2005). Clay minerals as alteration products in basaltic volcaniclastic deposits of La Palma (Canary Islands, Spain). Sedimentary Geology, 174, 237-253. https://doi.org/10.1016/j.sedgeo.2004.12.007

Giggenbach, W. F. (1984). Mass transfer in hydrothermal alteration systems-A conceptual approach. Geochimica et Cosmochimica Acta, 48, 2693-2711. https://doi.org/10.1016/0016-7037(84)90317-X

Giles, M. R. (1997). Diagenesis: A quantitative perspective - Implications for basin modelling and rock property prediction. Kluwer Academic Publishers.

Gislason, S. R., \& Oelkers, E. H. (2014). Carbon Storage in Basalt. Science, 344, 373-374. https://doi.org/10.1126/science.1250828

Greenfield, L., Millett, J. M., Howell, J., Jerram, D. A., Watton, T., Healy, D., et al. (2020). The 3D facies architecture and petrophysical properties of hyaloclastite delta deposits: An integrated photogrammetry and petrophysical study from southern Iceland. Basin Research, 32, 1091-1114. https://doi.org/10.1111/bre.12415

Griffiths, L., Heap, M. J., Xu, T., Chen, C.-f., \& Baud, P. (2017). The influence of pore geometry and orientation on the strength and stiffness of porous rock. Journal of Structural Geology, 96, 149-160. https://doi.org/10.1016/j.jsg.2017.02.006

Harnois, I. (1988). The CIW index: A new chemical index of weathering. Sedimentary Geology, 55, 319-322. https://doi. org/10.1016/0037-0738(88)90137-6

Harry, D. L., Tejada, M. L. G., Lee, E. Y., Wolfgring, E., Wainman, C. C., Brumsack, H.-J., et al. (2020). Evolution of the southwest Australian rifted continental margin during breakup of East Gondwana: Results from International Ocean Discovery Program Expedition 369. Geochemistry, Geophysics, Geosystems, 21, e2020GC009144. https://doi.org/10.1029/2020GC009144

Hashin, Z., \& Shtrikman, S. (1963). A variational approach to the theory of the elastic behaviour of multiphase materials. Journal of the Mechanics and Physics of Solids, 11, 127-140. https://doi.org/10.1016/0022-5096(63)90060-7

Heap, M. J., Xu, T., \& Chen, C. F. (2014). The influence of porosity and vesicle size on the brittle strength of volcanic rocks and magma. Bulletin of Volcanology, 76, 1-15. https://doi.org/10.1007/s00445-014-0856-0

Helm-Clark, C. M., Rodgers, D. W., \& Smith, R. P. (2004). Borehole geophysical techniques to define stratigraphy, alteration and aquifers in basalt. Journal of Applied Geophysics, 55, 3-38. https://doi.org/10.1016/j.jappgeo.2003.06.003

Houston, E. C., \& Smith, J. V. (1997). Assessment of rock quality variability due to smectitic alteration in basalt using X-ray diffraction analysis. Engineering Geology, 46, 19-32. https://doi.org/10.1016/S0013-7952(96)00067-1

Huber, B. T., Hobbs, R. W., Bogus, K. A., Batenburg, S. J., Brumsack, H.-J., do Monte Guerra, R., et al. (2019a). Methods. In R. W. Hobbs, B. T. Huber, K. A. Bogus, \& Expedition 369 Scientists. (Eds.), Australia Cretaceous Climate and Tectonics. Proceedings of the International Ocean Discovery Program. IODP. https://doi.org/10.14379/iodp.proc.369.102.2019 
Huber, B. T., Hobbs, R. W., Bogus, K. A., Batenburg, S. J., Brumsack, H.-J., do Monte Guerra, R., et al. (2019b). Site U1513. In R. W. Hobbs, B. T. Huber, K. A. Bogus, \& Expedition 369 Scientists (Eds.), Australia Cretaceous Climate and Tectonics. Proceedings of the International Ocean Discovery Program. IODP. https://doi.org/10.14379/iodp.proc.369.104.2019

Hyndman, R. D., \& Drury, M. J. (1977). Physical properties of basalts, gabbros, and ultramafic rocks from DSDP Leg 37. In F. Aumento, W. G. Melson, J. M. Hall, H. Bougault, L. Dmitriev, J. F. Fischer, et al. (Eds.), Initial reports of the Deep Sea Drilling Project (Vol. 37, pp. 395-401). U.S. Government Printing Office. https://doi.org/10.2973/DSDP.PROC.37.113.1977

Jerram, D. A., Millett, J. M., Kück, J., Thomas, D., Planke, S., Haskins, E., et al. (2019). Understanding volcanic facies in the subsurface: A combined core, wireline logging and image log data set from the PTA2 and KMA1 boreholes, Big Island, Hawai'i. Scientific Drilling, 25, 15-33. https://doi.org/10.5194/sd-25-15-2019

Jiang, F., Cheng, R., Ruan, B., Lin, B., Xu, Z., \& Li, Z. (2017). Formation mechanism of volcanic reservoirs within a volcanostratigraphic framework: The case of the Wangfu fault depression in the Songliao Basin, China. Marine and Petroleum Geology, 84, 160-178. https:// doi.org/10.1016/j.marpetgeo.2017.03.036

Kanakiya, S., Adam, L., Esteban, L., Rowe, M. C., \& Shane, P. (2017). Dissolution and secondary mineral precipitation in basalts due to reactions with carbonic acid. Journal of Geophysical Research: Solid Earth, 122, 4312-4327. https://doi.org/10.1002/2017JB014019

Kim, Y., Lee, C., \& Lee, E. Y. (2018). Numerical analysis of sedimentary compaction: Implications for porosity and layer thickness variation. Journal of the Geological Society of Korea, 54, 631-640. https://doi.org/10.14770/jgsk.2018.54.6.631

Kim, Y., Yi, S., Kim, G.-Y., Lee, E., \& Kong, S. (2019). Palynological study of paleoclimate and paleoceanographic changes in the Eastern South Korea Plateau, East Sea, during the Plio-Pleistocene climate transition. Palaeogeography, Palaeoclimatology, Palaeoecology, 520, 18-29. https://doi.org/10.1016/j.palaeo.2019.01.021

Kristinsdóttir, L. H., Flóvenz, O. G., Árnason, K., Bruhn, D., Milsch, H., Spangenberg, E., \& Kulenkampff, J. (2010). Electrical conductivity and P-wave velocity in rock samples from high-temperature Icelandic geothermal fields. Geothermics, 39(1), 94-105. https://doi. org/10.1016/j.geothermics.2009.12.001

Le Blond, J. S., Cuadros, J., Molla, Y. B., Berhanu, T., Umer, M., Baxter, P. J., \& Davey, G. (2015). Weathering of the Ethiopian volcanic province: A new weathering index to characterize and compare soils. American Mineralogist, 100, 2518-2532. https://doi.org/10.2138/ am-2015-5168CCBY

Lee, E. Y., Kominz, M., Reuning, L., Gallagher, S. J., Takayanagi, H., Ishiwa, T., et al. (2021). Quantitative compaction trends of Miocene to Holocene carbonates off the west coast of Australia. Australian Journal of Earth Sciences, 1-13. https://doi.org/10.1080/08120099.2 021.1915867

Lee, E. Y., \& Song, I. (2021). Data report: Moisture and Density (MAD) analysis and Ultrasonic velocity of Hole U1513E, IODP Expedition 369. In R. W. Hobbs, B. T. Huber, K. A. Bogus, \& Expedition 369 Scientists. (Eds.), Australia Cretaceous Climate and Tectonics. Proceedings of the International Ocean Discovery Program. IODP. https://doi.org/10.14379/iodp.proc.369.204.2021

Lee, E. Y., Wolfgring, E., Tejada, M. L. G., Harry, D. L., Wainman, C. C., Chun, S. S., et al. (2020). Early Cretaceous subsidence of the Naturaliste Plateau defined by a new record of volcaniclastic-rich sequence at IODP Site U1513. Gondwana Research, 82, 1-11. https://doi. org/10.1016/j.gr.2019.12.007

Lévy, L., Gibert, B., Sigmundsson, F., Flóvenz, Ó. G., Hersir, G. P., Briole, P., \& Pezard, P. A. (2018). The role of smectites in the electrical conductivity of active hydrothermal systems: Electrical properties of core samples from Krafla volcano, Iceland. Geophysical Journal International, 215(3), 1558-1582. https://doi.org/10.1093/gji/ggy342

Marion, D., \& Nur, A. (1991). Pore-filling material and its effect on velocity in rocks. Geophysics, 56, 225-230. https://doi. org/10.1190/1.1443034

Maritati, A., Halpin, J. A., Whittaker, J. M., Daczko, N. R., \& Wainman, C. C. (2021). Provenance of Upper Jurassic-Lower Cretaceous strata in the Mentelle Basin, southwestern Australia, reveals a trans-Gondwanan fluvial pathway. Gondwana Research, 93, 128-141. https:// doi.org/10.1016/j.gr.2020.12.032

Mathieu, L. (2018). Quantifying hydrothermal alteration: A review of methods. Geosciences, 8, 245. https://doi.org/10.3390/ geosciences 8070245

Mavko, G., Mukerji, T., \& Dvorkin, J. (2020). The rock physics handbook: Tools for seismic analysis of porous media (2nd ed.). Cambridge University Press. https://doi.org/10.1017/CBO9780511626753

McGrail, B. P., Schaef, H. T., Ho, A. M., Chien, Y.-J., Dooley, J. J., \& Davidson, C. L. (2006). Potential for carbon dioxide sequestration in flood basalts. Journal of Geophysical Research, 111, B12201. https://doi.org/10.1029/2005JB004169

Meszar, M., Gier, S., Palzer-Khomenko, M., Knierzinger, W., \& Wagreich, M. (2020). Clay mineralogy of Miocene mudstones from the Lower Austrian Molasse Basin. Austrian Journal of Earth Sciences, 113, 125-138. https://doi.org/10.17738/ajes.2020.0008

Mielke, P., Bär, K., \& Sass, I. (2017). Determining the relationship of thermal conductivity and compressional wave velocity of common rock types as a basis for reservoir characterization. Journal of Applied Geophysics, 140, 135-144. https://doi.org/10.1016/j.jappgeo.2017.04.002

Millett, J. M., Wilkins, A. D., Campbell, E., Hole, M. J., Taylor, R. A., Healy, D., et al. (2016). The geology of offshore drilling through basalt sequences: Understanding operational complications to improve efficiency. Marine and Petroleum Geology, 77, 1177-1192. https://doi. org/10.1016/j.marpetgeo.2016.08.010

Nara, Y., Meredith, P. G., Yoneda, T., \& Kaneko, K. (2011). Influence of macro-fractures and micro-fractures on permeability and elastic wave velocities in basalt at elevated pressure. Tectonophysics, 503(1-2), 52-59. https://doi.org/10.1016/j.tecto.2010.09.027

Navarre-Sitchler, A., Brantley, S. L., \& Rother, G. (2015). How porosity increases during incipient weathering of crystalline silicate rocks. Reviews in Mineralogy and Geochemistry, 80, 331-354. https://doi.org/10.2138/rmg.2015.80.10

Navelot, V., Géraud, Y., Favier, A., Diraison, M., Corsini, M., Lardeaux, J.-M., et al. (2018). Petrophysical properties of volcanic rocks and impacts of hydrothermal alteration in the Guadeloupe Archipelago (West Indies). Journal of Volcanology and Geothermal Research, 360, 1-21. https://doi.org/10.1016/j.jvolgeores.2018.07.004

Nesbitt, H. W., \& Young, G. M. (1982). Early Proterozoic climates and plate motions inferred from major element chemistry of lutites. Nature, 299, 715-717. https://doi.org/10.1038/299715a0

Nesbitt, H. W., \& Young, G. M. (1989). Formation and diagenesis of weathering profiles. The Journal of Geology, 97, 129-147. https://doi.org/10.1086/629290

Nur, A., Mavko, G., Dvorkin, J., \& Galmudi, D. (1998). Critical porosity: A key to relating physical properties to porosity in rocks. The Leading Edge, 17, 357-362. https://doi.org/10.1190/1.1437977

Olierook, H. K. H., Merle, R. E., \& Jourdan, F. (2017). Toward a Greater Kerguelen large igneous province: Evolving mantle source contributions in and around the Indian Ocean. Lithos, 282-283, 163-172. https://doi.org/10.1016/j.lithos.2017.03.007

Planke, S. (1994). Geophysical response of flood basalts from analysis of wire line logs: Ocean Drilling Program Site 642, Vøring volcanic margin. Journal of Geophysical Research, 99(B5), 9279-9296. https://doi.org/10.1029/94JB00496 
Planke, S., Alvestad, E., \& Eldholm, O. (1999). Seismic characteristics of basaltic extrusive and intrusive rocks. The Leading Edge, 18(3), 342-348. https://doi.org/10.1190/1.1438289

Planke, S., Cerney, B., Bücker, C. J., \& Nilsen, O. (1999). Alteration effects on petrophysical properties of subaerial flood basalts: Site 990, southeast Greenland margin. In H. C. Larsen, R. A. Duncan, J. F. Allan, \& K. Brooks (Eds.), Proceedings of the Ocean Drilling Program, scientific results (Vol. 163, pp. 17-28). ODP. https://doi.org/10.2973/odp.proc.sr.163.105.1999

Pola, A., Crosta, G., Fusi, N., Barberini, V., \& Norini, G. (2012). Influence of alteration on physical properties of volcanic rocks. Tectonophysics, 566-567, 67-86. https://doi.org/10.1016/j.tecto.2012.07.017

Pola, A., Crosta, G. B., Fusi, N., \& Castellanza, R. (2014). General characterization of the mechanical behaviour of different volcanic rocks with respect to alteration. Engineering Geology, 169, 1-13. https://doi.org/10.1016/j.enggeo.2013.11.011

Prasanna Lakshmi, K. J., Senthil Kumar, P., Vijayakumar, K., Ravinder, S., Seshunarayana, T., \& Sen, M. K. (2014). Petrophysical properties of the Deccan basalts exposed in the Western Ghats escarpment around Mahabaleshwar and Koyna, India. Journal of Asian Earth Sciences, 84, 176-187. https://doi.org/10.1016/j.jseaes.2013.08.028

Reuss, A. (1929). Berechnung der Fließgrenze von Mischkristallen auf Grund der Plastizitätsbedingung für Einkristalle. Zeitschrift für Angewandte Mathematik und Mechanik, 9, 49-58. https://doi.org/10.1002/zamm.19290090104

Révillon, S., Barr, S. R., Brewer, T. S., Harvey, P. K., \& Tarney, J. (2002). An alternative approach using integrated gamma-ray and geochemical data to estimate the inputs to subduction zones from ODP Leg 185, Site 801. Geochemistry, Geophysics, Geosystems, 3, 12. https:// doi.org/10.1029/2002GC000344

Riquier, L., Lee, E. Y., \& Tejada, M. L. G. (2021). Data report: XRD mineral identification of a volcanic sequence at 1 Site U1513 (Naturaliste Plateau), IODP Expedition 369. In R. W. Hobbs, B. T. Huber, K. A. Bogus, \& Expedition 369 Scientists. (Eds.), Australia Cretaceous Climate and Tectonics. Proceedings of the International Ocean Discovery Program. IODP. https://doi.org/10.14379/iodp.proc.369.205.2021

Rossetti, L. M., Healy, D., Hole, M. J., Millett, J. M., de Lima, E. F., Jerram, D. A., \& Rossetti, M. M. (2019). Evaluating petrophysical properties of volcano-sedimentary sequences: A case study in the Paraná-Etendeka Large Igneous Province. Marine and Petroleum Geology, 102, 638-656. https://doi.org/10.1016/j.marpetgeo.2019.01.028

Schenato, F., Formoso, M. L. L., Dudoignon, P., Meunier, A., Proust, D., \& Mas, A. (2003). Alteration processes of a thick basaltic lava flow of the Paraná Basin (Brazil): Petrographic and mineralogical studies. Journal of South American Earth Sciences, 16, 423-444. https://doi. org/10.1016/S0895-9811(03)00098-1

Schlegel, T. U., \& Heinrich, C. A. (2015). Lithology and hydrothermal alteration control the distribution of copper grade in the prominent hill iron oxide-copper-gold deposit (Gawler Craton, South Australia). Economic Geology, 110, 1953-1994. https://doi.org/10.2113/ econgeo.110.8.1953

Schreiber, E., \& Fox, P. J. (1977). Density and P-wave velocity of rocks from the FAMOUS region and their implication to the structure of the oceanic crust. GSA Bulletin, 88, 600-608. https://doi.org/10.1130/0016-7606(1977)88<600:dapvor >2.0.co;2

Scott, S. W., Covell, C., Júlíusson, E., Valfells, Á., Newson, J., Hrafnkelsson, B., et al. (2019). A probabilistic geologic model of the Krafla geothermal system constrained by gravimetric data. Geothermal Energy, 7, 29. https://doi.org/10.1186/s40517-019-0143-6

Searle, R. C. (2008). Magnetic susceptibility as a tool for investigating igneous rocks-Experience from IODP Expedition 304. Scientific Drilling, 6, 52-54. https://doi.org/10.2204/iodp.sd.6.08.2008

Self, S., Thordarson, T., \& Keszthelyi, L. (1997). Emplacement of continental flood basalt lava flows. In J. J. Mahoney, \& M. Coffin (Eds.), Large igneous provinces: Continental, oceanic, and planetary flood volcanism (pp. 381-410). American Geophysical Union. https://doi. org/10.1029/GM100p0381

Smith, D. S., Alzina, A., Bourret, J., Nait-Ali, B., Pennec, F., Tessier-Doyen, N., et al. (2013). Thermal conductivity of porous materials. Journal of Materials Research, 28, 2260-2272. https://doi.org/10.1557/jmr.2013.179

Sumirat, I., Ando, Y., \& Shimamura, S. (2006). Theoretical consideration of the effect of porosity on thermal conductivity of porous materials. Journal of Porous Materials, 13, 439-443. https://doi.org/10.1007/s10934-006-8043-0

Tartarotti, P., Fontana, E., \& Crispini, L. (2009). Deformation pattern in a massive ponded lava flow at ODP-IODP Site 1256: A core and log approach. Geochemistry, Geophysics, Geosystems, 10, Q05O17. https://doi.org/10.1029/2008GC002346

Tejada, M. L. G., Lee, E. Y., Chun, S. S., Harry, D. L., Riquier, L., \& Wainman, C. C. (2020). Data report: Petrology and volcanic stratigraphy at Site U1513, IODP Expedition 369. In R. W. Hobbs, B. T. Huber, K. A. Bogus, \& Expedition 369 Scientists. (Eds.), Australia Cretaceous Climate and Tectonics. Proceedings of the International Ocean Discovery program. IODP. https://doi.org/10.14379/iodp.proc.369.202.2020

Tominaga, M., Teagle, D. A. H., Alt, J. C., \& Umino, S. (2009). Determination of the volcanostratigraphy of oceanic crust formed at superfast spreading ridge: Electrofacies analyses of ODP/IODP Hole 1256D. Geochemistry, Geophysics, Geosystems, 10, Q01003. https://doi. org/10.1029/2008GC002143

Voigt, W. (1910). Lehrbuch der Kristallphysik. B.G. Teubner.

Wang, M., \& Pan, N. (2008). Predictions of effective physical properties of complex multiphase materials. Materials Science and Engineering: R: Reports, 63(1), 1-30. https://doi.org/10.1016/j.mser.2008.07.001

Wang, Y., Yang, R., Song, M., Lenhardt, N., Wang, X., Zhang, X., et al. (2018). Characteristics, controls and geological models of hydrocarbon accumulation in the Carboniferous volcanic reservoirs of the Chunfeng Oilfield, Junggar Basin, northwestern China. Marine and Petroleum Geology, 94, 65-79. https://doi.org/10.1016/j.marpetgeo.2018.04.001

White, L. T., Forster, M. A., Tanner, D., Tejada, M. L. G., Hobbs, R., \& IODP Expedition 369 Science Party. (2021). Age of magmatism and alteration of basaltic rocks cored at the base of IODP Site U1513, Naturaliste Plateau, southwestern Australia. Australian Journal of Earth Sciences, 1-23. https://doi.org/10.1080/08120099.2021.1963840

Wyering, L. D., Villeneuve, M. C., Wallis, L. C., Siratovich, P. A., Kennedy, B. M., Gravley, D. M., \& Cant, J. L. (2014). Mechanical and physical properties of hydrothermally altered rocks, Taupo Volcanic Zone, New Zealand. Journal of Volcanology and Geothermal Research, 288, 76-93. https://doi.org/10.1016/j.jvolgeores.2014.10.008

Xiong, W., Wells, R. K., Horner, J. A., Schaef, H. T., Skemer, P. A., \& Giammar, D. E. (2018). $\mathrm{CO}_{2}$ mineral sequestration in naturally porous basalt. Environmental Science and Technology Letters, 5, 142-147. https://doi.org/10.1021/acs.estlett.8b00047

Zakharova, N. V., Goldberg, D. S., Sullivan, E. C., Herron, M. M., \& Grau, J. A. (2012). Petrophysical and geochemical properties of Columbia River flood basalt: Implications for carbon sequestration. Geochemistry, Geophysics, Geosystems, 13, Q11001. https://doi. org/10.1029/2012GC004305 